\title{
O COLONIALISMO COMO TEORIA DA MODERNIDADE: ESBOÇO DE UMA PESQUISA INTERDISCIPLINAR EM TEORIA SOCIAL CRÍTICA
}

\section{[The colonialism as theory of modernity: outline of an interdisciplinary research on critical social theory]}

\author{
Leno Francisco Danner* \\ Fernando Danner* \\ Agemir Bavaresco*
}

\begin{abstract}
Resumo: a partir da crítica à cegueira histórico-sociológica das teorias da modernidade euronorcêntricas - utilizaremos a teoria da modernidade de Jürgen Habermas como caso exemplar -, defenderemos que o colonialismo se constitui em uma frutífera e consistente teoria da modernidade que permite a desconstrução dessa cegueira histórico-sociológica, caracterizada (a) pela formulação de um discurso filosófico-sociológico da modernidade sobre si mesma que, se por um lado é autorreferencial, autosubsistente e endógeno, por outro, ao fim e ao cabo, descobre o gênero humano, imbricando diretamente modernização, racionalização, universalismo e gênero humano, modernização como gênero humano; (b) pela separação entre modernidade cultural e modernização econômico-social, a primeira enquanto esfera puramente normativa, a segunda como esfera basicamente lógico-técnica, instrumental, de modo que, por essa separação, a modernidade cultural aparece pura e santa, autêntico universalismo sob a forma de racionalização cultural-comunicativa e procedimentalismo imparcial, neutro, formal e impessoal, ao passo que a modernização econômico-social passa a ser a única causa das patologias psicossociais modernas por isso, a modernidade cultural pode ser defendida em sua universalidade, contra qualquer crítica dirigida à modernização; (c) pelo apagamento e pelo silenciamento do colonialismo como parte constitutiva fundamental da teoria da modernidade, uma vez que, se ele fosse colocado como conseqüência da própria modernização, haveria a necessidade de se correlacionar modernidade cultural e modernização econômico-social, o que implodiria a pretensão de a modernidade servir como universalismo epistemológico-político, como guarda-chuva normativo de todas as diferenças, como condição da crítica, da reflexividade e da emancipação; e (d) a separação, como ponto de partida e préconceito político-normativo das teorias da modernidade, entre modernidade europeia como racionalização e universalismo versus todo o resto como tradicionalismo em geral, dogmático e preso ao contexto de emergência. Com isso, defenderemos que o colonialismo como teoria da modernidade permite trazer-se para dentro desta a própria voz-práxis das vítimas, dos sujeitos epistemológico-políticos e dos contextos socioculturais periferizados, colonizados, o que possibilitaria a reconstrução e a correçãocomplementação dessa mesma teoria da modernidade.
\end{abstract}

\footnotetext{
${ }^{*}$ Doutor em Filosofia (PUCRS). Professor de Filosofia e de Sociologia no Departamento de Filosofia da Universidade Federal de Rondônia (UNIR), Email: leno_danner@yahoo.com.br.

* Doutor em Filosofia (PUCRS). Professor de Filosofia na Universidade Federal de Rondônia (UNIR), email: fernando.danner@gmail.com.

*Doutor em Filosofia (Université de Paris I - Pantheon Sorbonne). Professor do Programa de PósGraduação em Filosofia da Pontifícia Universidade Católica do Rio Grande do Sul (PUCRS), email: abavaresco@pucrs.br.
} 
Palavras-Chave: Modernidade; Colonialismo; Universalismo; Cegueira Histórico-Sociológica; Decolonialidade.

\begin{abstract}
Euronorcentric theories of modernity - we will use Habermas' theory of modernity as example - we will argue that the colonialism is a very fruitful and consistent theory of modernity which allows the deconstruction of that historical-sociological blindness characterized (a) for the formulation of a philosophical-sociological discourse of modernity by itself that, if on the one hand it is self-referential, self-subsisting and endogenous, on the other hand it discovers the humankind, linking directly modernization, rationalization, universalism and humankind, modernization as humankind; (b) for the separation between cultural modernity and social-economic modernization, the first as a purely normative sphere, the second as basically logical-technical or instrumental sphere, so that, from this separation, cultural modernity appears pure and holly, an authentic universalism as cultural-communicative rationalization and as impartial, neutral, formal and impersonal proceduralism, while social-economic modernization is the only cause of the modern psychosocial pathologies - because of that, cultural modernity can be defended in its universality, against any criticism directed to modernization at all; (c) for the deletion and silencing of the colonialism as fundamental constitutive part of the theory of modernity, because, if it were put as consequence of the modernity itself, it would be necessary the correlation between cultural and socialeconomic modernity, which would implode the modernity's intention of serving as epistemological-moral universalism, as normative umbrella of all differences, as condition of criticism, reflexivity and emancipation; and (d), as the theory of modernity's starting point and political pre-concept, the separation between European modernity as rationalization and universalism versus all the rest as traditionalism in general, dogmatic and attached to its context of emergence. From that, we will defend that the colonialism as theory of modernity enables to bring inside modernity the voice-praxis of the victims, of the peripheral or colonized epistemological-political subjects and contexts, what would allow the reconstruction and the correction-complementation of the own theory of modernity.
\end{abstract}

Key-Words: Modernity; Colonialism; Universalism; Historical-Sociological Blindness; Decoloniality.

\title{
Considerações iniciais
}

O colonialismo enquanto fenômeno simbólico-normativo e político-material não aparece nas teorias da modernidade europeias, nem encontra nelas centralidade em termos de análise epistemológico-política; ele não é citado por elas, quando da sua reconstrução filosófico-sociológica do processo de constituição, de desenvolvimento e de consolidação dessa mesma modernização como um sistema-mundo que é, em primeiro lugar, um processo ontogenético de constituição-desenvolvimentoconsolidação endógeno, autorreferencial e auto-subsistente da Europa sobre si mesma e para si mesma e, depois, das sociedades industrializadas desenvolvidas contemporâneas sobre si mesmas e para si mesmas (este como herança-continuidade daquele) inclusive, em muitos casos, a separação entre primeiro e terceiro mundos, entre capitalismo central e capitalismo periférico, foi entendida como apontando para sendas 
evolutivas singulares, e não como processos correlatos e mutuamente dependentes de constituição-desenvolvimento. No máximo, o colonialismo simbólico-material aparece como um acontecimento fortuito, secundário, periférico àquele grande processo modernizante que é, fundamentalmente, um trabalho de si sobre si mesmo, um autoesforço hercúleo de superação do tradicionalismo em vista da consolidação da moderna visão de mundo - calcada no racionalismo e no universalismo - em termos societaisculturais e cognitivo-morais. Ao menos esse é o quadro teórico-político quando analisamos os discursos filosófico-sociológicos de grandes pensadores europeus de fins do século XIX em diante, em especial, para sermos mais específicos, Max Weber e a grande tradição da teoria crítica europeia na figura de Jürgen Habermas.

Nesse texto, focando particularmente em Max Weber e em Jürgen Habermas, procuraremos defender que, de fato, o discurso filosófico-sociológico da modernidade europeia sobre si mesma é marcado por uma cegueira histórico-sociológica (e até normativa) caracterizada pelos seguintes passos e pressuposições teórico-políticos, a saber: (a) é um discurso-processo autorreferencial, auto-subsistente e endógeno da modernidade sobre si mesma, que parte da diferenciação e da oposição entre a modernidade europeia, racional e universal, versus todo o resto como tradicionalismo em geral, dogmático e contextualista; (b) esse discurso-processo correlaciona (e, depois, contrapõe) modernidade-modernização, racionalismo e universalismo, bem como tradicionalismo, dogmatismo e contextualismo, o que significa a afirmação de que a modernidade, por meio da racionalização, gera crítica, reflexividade e emancipação, uma vez que é uma sociedade-cultura, consciência cognitivo-moral e paradigma normativo universalistas, ao passo que o tradicionalismo em geral não é racional e nem gera racionalização social, não permitindo, por conseguinte, a perspectiva teóricoprática universal e nem a consecução do criticismo social e da reflexividade política caudatários dessa mesma perspectiva teórico-prática universal; no mesmo sentido, (c) esse discurso-processo da modernidade-modernização sobre si mesma separa metodológico-programaticamente modernidade cultural enquanto esfera basicamente normativa e modernização econômico-social como esfera fundamentalmente materialinstitucional, tornando a primeira condição ontogenética da segunda, mas eximindo-a de qualquer patologia psicossocial, que fica diretamente ligada à modernização econômicosocial, o que implica em que, por tal separação, a modernidade cultural pode ser afirmada como o autêntico universalismo epistemológico-moral (enquanto sociedade- 
cultura, consciência cognitivo-moral e paradigma normativo descentrados, póstradicionais), como a condição da crítica, da reflexividade e da emancipação, como o guarda-chuva por excelência das diferenças, para as diferenças e pelas diferenças, culpando-se apenas a modernização econômico-social das patologias psicossociais geradas em termos de modernização ocidental; com isso, (d) esse discurso-processo realiza a exclusão e o apagamento do colonialismo como ponto fundante e definidor da modernização, como consequiência da modernização enquanto correlação de modernidade cultural e modernização econômico-social como um processo imbricado e mutuamente dependente, de modo a, mais uma vez, salvar a modernidade cultural em seu sentido universalista, como guarda-chuva normativo e paradigma epistemológicopolítico de todos os contextualismos e particularismos.

Desse modo, defenderemos que esse discurso-processo filosófico-sociológico da modernidade europeia sobre si mesma, nas características caricatas por ele assumidas, conforme apresentado acima e conforme desenvolveremos logo adiante, não permite uma perspectiva crítica e reflexiva nem ao paradigma normativo da modernidade calcado na modernidade cultural (correlação de modernização, racionalização e universalismo via procedimentalismo imparcial, neutro, formal e impessoal enquanto o resultado mais fundamental dessa mesma modernidade cultural), que se afirma como o guarda-chuva normativo de todas as diferenças, para todas elas e por todas elas, e nem, principalmente, uma práxis decolonial ou anti-colonial própria às sociedades-culturas e aos sujeitos epistemológico-políticos periféricos, excluídos, gerados em termos do colonialismo levado a efeito pela modernidade enquanto sistema-mundo totalizante e desde a correlação de modernidade cultural, modernização econômico-social e o próprio colonialismo. Por isso, proporemos, nas páginas que se seguem, a partir da crítica à cegueira histórico-sociológica das teorias da modernidade, que esse discurso filosóficosociológico da modernidade sobre si mesma, que a concebe como autêntico universalismo, somente pode ser realizado de modo crítico, reflexivo, emancipatório e, então, universalista se o colonialismo for trazido para o centro desse mesmo discurso, isto é, se ele for concebido como um pilar fundamental da constituição, da autocompreensão e do próprio desenvolvimento da modernidade euronorcêntrica e, com isso, como imbricando modernidade cultural e modernização econômico-social (até porque o colonialismo é sempre simbólico-normativo e político-material - é necessária a negação simbólica, normativa e moral como condição da instrumentalização e até da 
destruição material). Nesse caso, a reparação pelo colonialismo, e não mais a modernidade cultural (enquanto procedimentalismo imparcial, neutro, formal e impessoal, enquanto racionalização cultural-comunicativa), ofereceria a base normativa da práxis, servindo, inclusive, como voz-práxis do outro da modernidade.

Com isso, apontaremos que as ciências humanas e sociais do horizonte da modernidade periférica e a partir dela, uma vez fundadas na assunção do colonialismo como teoria da modernidade e na sua utilização como chave-de-leitura e mote normativo da práxis epistemológico-política decolonial, podem reconstruir o discurso filosófico-sociológico da modernidade, agora por meio do e a partir do próprio sujeitocontexto excluído-marginalizado-colonizado, que traz para dentro da teoria da modernidade e como voz-práxis desse mesmo excluído-marginalizado-colonizado as experiências correlatas de negação-deslegitimação simbólico-normativa e de destruição político-material, tendo condições de, no mesmo diapasão, apresentar valores, práticas, símbolos e formas de vida alternativas à própria modernização econômico-cultural. Em verdade, o sujeito epistemológico-político colonizado tem condições de, por meio da utilização do colonialismo como base fundante e definidora e também como resultado do processo de evolução da modernidade-modernização, expor a profunda ligação entre cultura e civilização material, geralmente ignorada-silenciada pelas teorias da modernidade tradicionais (por exemplo, no caso da teoria da modernidade de Habermas) que também faz parte do processo de modernização europeu - ligação essa que, de resto, faz parte da constituição, da organização, do desenvolvimento e da evolução de qualquer sociedade-cultura. Essa profunda ligação e dependência entre modernidade cultural e modernização econômico-social, juntamente com a colocação do colonialismo como ponto nodal da constituição-desenvolvimento-evolução da modernidade, permitem o desvelamento, a crítica e a desconstrução da cegueira histórico-sociológica das teorias da modernidade, além da suspeição relativamente à direta associação entre modernidade-modernização, racionalização, crítica, reflexividade, emancipação, universalismo e gênero humano - modernidade como gênero humano, como ápice, apogeu dele - que aparece como resultado direto do discurso filosófico-sociológico da modernidade sobre si mesma. Desse modo, nosso texto, ao defender o colonialismo como teoria da modernidade por excelência, uma vez que ele religa modernidade cultural, modernização econômico-social e colonialismo, aponta para uma filosofia decolonial como a base teórico-política das periferias 
socioculturais e epistemológico-políticas, por meio de seus sujeitos epistemológicopolíticos periferizados, negados, excluídos: aqui, portanto, a voz-práxis emancipatória é dada exatamente desde a periferia, desde a colônia, e por meio dos sujeitos epistemológico-políticos marginalizados, inferiorizados em termos de constituição e de desenvolvimento da modernização totalizante.

\section{A teoria da modernidade, a Europa e o outro da modernidade: sobre a construção do discurso filosófico-sociológico da modernidade}

O discurso filosófico-sociológico da modernidade é, conforme pensamos, um dos pontos mais fundamentais da filosofia e da sociologia europeias desde pelo menos fins do século XVIII, em que as idéias de um novo tempo, de uma nova sociedade, de uma nova cultura, de um novo indivíduo-homem e, correlatamente, de uma nova proposta epistemológico-política e antropológico-ontológica, representadas por essa mesma Europa em termos societais-culturais, político-antropológicos e normativos, passam a ser ponto fundante e referência explícita nas produções de uma ampla gama de autores, passando por Kant, encontrando seu ápice em Hegel, passando, além disso, por Comte e Marx, por Nietzsche, Durkheim e Heidegger, etc. No mesmo sentido, a sociologia weberiana e, depois, a teoria social frankfurtiana, em particular no caso de Habermas, assumem exatamente a elaboração desse discurso como condição fundamental para pensar-se a relação teoria e práxis e, em verdade, para definir-se o tipo de abordagem relativamente à modernidade-modernização ocidental. Pode-se dizer, com isso, que a modernidade-modernização é o núcleo comum - ainda que percebida desde diferentes vieses e com características muito específicas a cada posição teóricopolítica -, o ponto de partida, a base de dinamização e certamente o ponto de chegada de todas essas posições filosófico-sociológicas. Nesse sentido, a abordagem dada à modernidade-modernização, o conceito de modernidade-modernização, uma vez definido, permite, como consequência, exatamente um tipo de criticismo social e de práxis política muito específicos, para não se falar também de uma postura estéticoepistemológica frente a si mesmo, aos outros e ao mundo.

A construção de um discurso filosófico-sociológico da modernidade, como herança mais fundamental da filosofia e das ciências sociais europeias, é a intençãochave, o mote dinamizador de toda a excelente e instigante pesquisa de Jürgen Habermas. Com efeito, como ele salienta em muitos de seus escritos, a intenção dessa 
reconstrução a uma só vez filosófica e sociológica consiste em oferecer um contraponto às abordagens unidimensionais - tanto em teoria crítica quanto em termos de pósestruturalismo, tanto à esquerda quanto à direita do espectro político - acerca da modernidade, mostrando exatamente seu sentido plurívoco ou, pelo menos, para dizer o mínimo, seu sentido dual (cf.: Habermas, 1991, p. 166; 2012a, p. 09-14; Habermas, 1997, p. 33-34, p. 140-154). Para Habermas, reduzir a compreensão da modernidademodernização a um único princípio, por exemplo o trabalho ou a racionalidade instrumental (como o fizeram Marx, Weber e Adorno \& Horkheimer, no entender do pensador em comento), implica em perder de vista toda a amplitude e riqueza dessa revolucionária base societal-cultural, antropológico-ontológica e epistemológicopolítica que é a modernidade (cf.: Habermas, 2012a, p. 267-268). No mesmo sentido, se quisermos - como Habermas quis - enfrentar o conservadorismo político-cultural, que compreende a modernidade como a época do relativismo, do individualismo e do ceticismo, precisamos de entender o que é a modernidade (cf.: Habermas, 1997, p. 140141, p. 179). Se quisermos, ainda, pensar nas perspectivas de uma esquerda teóricopolítica frente à economia, ao Estado e à sociedade civil, necessitamos de reconstruir esse discurso filosófico-sociológico da modernidade, não mais unidimensional, mas exatamente plural, fazendo jus à amplitude e às diferenciações da modernidade (cf.: Habermas, 2003a, p. 11-13; Habermas, 2005, p. 127-143).

Em suma, fiel à tradição filosófico-sociológica europeia, que buscava na filosofia a fundamentação de um conceito objetivo de normatividade social garantidor da crítica, da reflexividade e da emancipação via práxis, e que buscava na sociologia um conceito objetivo de fato e de sujeito e de instituição sociais, Habermas quer, por meio de sua proposta de um discurso filosófico-sociológico da modernidade, dotar a teoria social crítica de uma base teórico-política capaz de, por um lado, avaliar a modernidademodernização (europeia e, depois, o padrão evolutivo-constitutivo das sociedades industrializadas desenvolvidas) em todas as suas potencialidades, bem como, por outro, perceber efetivamente suas patologias psicossociais, de modo a ter-se, com isso, uma base normativo-institucional que possa permitir sua diagnose e sua superação. Para isso, Habermas tem de construir correlatamente um conceito normativo e um conceito institucional-empírico de modernidade que possam dar suporte tanto ao criticismo social quanto à práxis política. Ora, mas como Habermas é filho e continuador da tradição iluminista moderna, também é de se esperar que o criticismo social e a práxis 
política emancipatória em termos de teoria crítica e a partir de um conceito de modernidade-modernização plural ou dual encontrem suporte em uma posição epistemológico-política universalista, isto é, em um paradigma normativo que não se restrinja apenas à própria modernidade, senão que tenha alcance maior, no próprio horizonte intercultural. Assim, o discurso filosófico-sociológico da modernidade por si mesma, sobre si mesma e para si mesma é também um discurso do gênero humano sobre si mesmo, para si mesmo e por si mesmo - da modernidade para o gênero humano, e deste para aquela (cf.: Habermas, 1990a, p. 13-21, p. 153, p. 194-228; Habermas, 1999, p. 31-43).

Ora, como dissemos, Habermas - situando-se na grande tradição da filosofia e da sociologia modernas, que têm, portanto, na categoria de modernidade-modernização sua base epistemológica, política e normativa (e certamente antropológico-ontológica) tem por objetivo construir-reconstruir o processo de evolução da modernidade europeia com vistas a oferecer um contraponto às avaliações unidimensionais feitas dela, permitindo, com isso, sua retomada como fundamento da crítica social, da emancipação política e do universalismo epistemológico-moral ou do diálogo-práxis intercultural. Importante mencionar, no que diz respeito a essa reconstrução, que, quando falamos em modernidade-modernização de um modo geral e no caso de Habermas em particular, estamos falando na Europa moderna e, depois, no padrão evolutivo das sociedades industrializadas desenvolvidas (nesse caso, América do Norte e Europa Ocidental) (cf.: Habermas, 2012a, p. 355; Habermas, 2012b, p. 551; Habermas, 1999, p. 50-80). Nas análises filosófico-sociológicas de fins do século XVIII em diante e, em especial, na filosofia e na sociologia do século XX, quando o conceito de modernidademodernização é utilizado, ele o é exatamente para significar esse contexto social, cultural e normativo da modernidade-modernização central. Como veremos mais adiante, é nele que Habermas (assim como a grande tradição filosófico-sociológica que assume, da qual faz parte) percebe o grande ponto de viragem da história da evolução humana e, nesse sentido, o potencial efetivamente emancipatório, crítico e universalista que embasa a construção de seu conceito de racionalidade cultural-comunicativa como o núcleo comum da espécie humana como um todo - em primeiro lugar, a racionalidade cultural-comunicativa manifestou-se e consolidou-se em toda a sua pujança na Europa moderna, embora faça parte de todas as sociedades-culturas enquanto sua base 
ontogenética e dinamizadora, mesmo que não com tanta força, intensidade e radicalidade.

O discurso filosófico-sociológico da modernidade é um discurso da modernidade europeia sobre si mesma, para si mesma e por si mesma, da mesma forma como ele é, depois, um discurso da modernidade-modernização central sobre si mesma, para si mesma e por si mesma. O que tem a modernidade-modernização europeia de tão especial que leva Habermas - assim como levou seus mestres na grande tradição filosófico-sociológica à qual ele se filia e dá continuidade - a utilizá-la como chave-deleitura analítica e conceito político-normativo? A resposta é bem óbvia e totalmente alinhada àquela tradição filosófico-sociológica da qual Habermas é herdeiro e continuador: há uma correlação umbilical entre modernidade-modernização, racionalização, universalismo e gênero humano, assim como há uma correlação fundamental entre modernidade-modernização, razão, crítica, reflexividade e emancipação. E, o que é mais importante, a modernidade europeia, pela primeira vez na história e na evolução do gênero humano, e como autocompreensão do gênero humano por si mesmo, alcançou essa correlação, tornando-se, por meio da razão-racionalização, uma sociedade-cultura, uma consciência cognitivo-moral e um paradigma epistemológico-político efetivamente universalistas, o autêntico guarda-chuva normativo de todas as diferenças, para todas elas, por todas elas (cf.: Habermas, 2012a, p. 355, p. 383-385; Habermas, 1997, p. 163). Não por acaso, aqui, a comparação entre modernidade e tradicionalismo e a diferença entre a modernidade como racionalização e universalismo e todo o resto como tradicionalismo em geral enquanto dogmatismo e contextualismo estritos são o ponto de partida e o pré-conceito político basilares, fundantes do discurso filosófico-sociológico da modernidade, de Habermas e da tradição filosófico-sociológica da qual ele faz parte.

Essa diferenciação - e o espanto que os pensadores europeus sentem em relação a ela - faz parte da teoria da modernidade de Weber, definindo o estilo de suas análises sociológicas referentemente ao fenômeno da modernização e, claro, dos seus estudos sobre religiões e organizações sociais orientais (não por acaso, a sociologia europeia assume em cheio essa diferenciação e oposição entre Ocidente e Oriente). Com efeito, para Weber, quando nós, os filhos da modernidade-modernização, olhamos para a história universal, podemos perceber de modo direto exatamente a diferença entre a modernidade europeia e todo o resto como ponto fundante para pensarmos a própria 
condição da modernidade-modernização e, com isso, as perspectivas antropológicoontológicas, socioculturais e epistemológico-políticas correlatas, caudatárias a essa mesma civilização ocidental em termos de modernidade-modernização. Com efeito, segundo Weber,

O filho da moderna civilização ocidental, que trata de problemas histórico-universais, o faz de modo inevitável e lógico a partir da seguinte dinâmica: que encadeamento de circunstâncias possibilitou que aparecessem no Ocidente, e somente no Ocidente, fenômenos culturais (pelo menos como os representamos a nós) que apresentam uma direção evolutiva de alcance e de validade universais? (Weber, 1984, p. 11; os destaques são nossos).

Perceba-se, aqui, o primeiro ponto teórico-político definidor do discurso filosófico-sociológico da modernidade europeia sobre si mesma, que é exatamente a correlação de historicismo e universalismo, o que implica, aliás, de que somente em termos de Ocidente e por parte do Ocidente ocorram valores, práticas e sujeitos com vinculação, sentido e atuação universais, isto é, com uma perspectiva antropológicoontológica, sociocultural e epistemológico-política transcendentes ao contexto. Mas por que a modernidade, e não qualquer outra sociedade-cultura, tem tanto essa correlação de historicismo e de universalismo quanto essa vinculação, esse sentido e essa atuação de alcance universais, ou seja, em nome de toda a humanidade e por parte dela, a partir dela? Qual categoria antropológico-ontológica, sociocultural e epistemológico-política permite e gera esse universalismo próprio à modernidade-modernização europeia? Weber responde: a racionalização cultural (cf.: Weber, 1984, p. 11-24). Esse é o aspecto fundante, dinamizador e definidor da modernidade-modernização e, ao mesmo tempo, ele é o umbral que separa a modernidade europeia em relação a todo o resto como tradicionalismo. Segue Weber:

Por que, nestes lugares, não ocorreram seja a evolução científica, seja o desenvolvimento da ciência, seja o desenvolvimento da arte e o do Estado, assim como o da economia, pelos caminhos da racionalização que são característicos do Ocidente? Pois é evidente que, em todos os casos mencionados, se trata de um 'racionalismo' de tipo especial da cultura ocidental (Weber, 1984, p. 20; o destaque é de Weber).

Ora, é esse racionalismo de tipo especial da modernidade europeia que, como dissemos acima, separa a modernidade enquanto racionalização e universalismo 
relativamente a todo o resto como tradicionalismo em geral, de modo que um discurso filosófico-sociológico da modernidade sobre si mesma encontra nesta categoria e na diferenciação-oposição que ela pressupõe exatamente seu ponto de partida e seu mote teórico-políticos. Com efeito, no caso do sentido e do mote do discurso filosóficosociológico da modernidade europeia sobre si mesma, por si mesma e a partir de si mesma, o objetivo central consiste em "[...] conhecer a peculiaridade específica do racionalismo ocidental e, dentro dele, do racionalismo ocidental moderno, bem como de explicá-lo em sua gênese" (Weber, 1984, p. 21; o destaque é de Weber). Note-se que, em relação a isso, poder-se-ia objetar que a posição de Weber tanto em relação à especificidade da Europa moderna - porque, quando ele fala em civilização ocidental, é à Europa moderna que ele está se referindo, como o provam suas pesquisas - quanto em relação à contraposição, com base na categoria da racionalização, entre essa mesma Europa moderna e todo o resto como tradicionalismo seria apenas um ponto de partida metodológico-programático em termos de realização das pesquisas em ciências sociais, sem necessariamente estar comprometido com ou dependente de uma avaliação e de um enquadramento axiológicos mais amplos relativamente à superioridade ou à inferioridade de uma estrutura societal-cultural e epistemológico-política. Por outras palavras, quando Weber compara e opõe a modernidade europeia versus todo o resto como tradicionalismo, não necessariamente estaria em jogo, aqui, um juízo de valor sobre a superioridade ou a inferioridade de uma em relação à outra, do tradicionalismo em relação à modernidade-modernização. Trata-se, mais uma vez, de uma hipótese de pesquisa, de uma chave de leitura analítica para a abordagem propriamente sociológica.

Ora, se isso pode ser verdade para Weber, o mesmo não acontece com Habermas. Com efeito, para Habermas, essa correlação de modernização, racionalização e universalismo, assim como, em conseqüência, a separação entre modernidade europeia e todo o resto como tradicionalismo é não apenas um ponto de partida metodológico-programático, uma chave de leitura analítica para o entendimento e a reconstrução do processo de constituição e de evolução da modernidademodernização, senão que um juízo epistemológico, político e normativo acerca da superioridade da sociedade-cultura, da consciência cognitivo-moral e do paradigma normativo modernos em termos de efetivamente gerarem racionalização social-culturalcomunicativa e, com isso, fundarem exatamente uma sociedade-cultura, uma consciência cognitivo-moral e um paradigma normativo universalistas. Se por um lado 
Habermas alerta que isso não significa que o indivíduo de uma sociedade tradicional é inferior cognitivamente falando em relação ao indivíduo moderno, por outro ele está afirmando que, sim, a estrutura sociocultural, cognitivo-moral e paradigmáticonormativa da modernidade é superior em relação ao tradicionalismo exatamente por gerar, por fundar e por dinamizar a perspectiva sociocultural, antropológico-ontológica e epistemológico-política universalista (cf.: Habermas, 2012a, p. 95-96). Portanto, a separação entre modernidade e todo o resto, a associação de modernidade, racionalização e universalização, assim como a superioridade da modernidade (por causa da racionalização e do universalismo) em relação a todo o resto como tradicionalismo em geral, representam o ponto de partida epistemológico e o préconceito político-normativo fundantes da teoria da modernidade de Habermas. Ele diz, ao justificar essa base do discurso filosófico-sociológico da modernidade sobre si mesma:

À medida que procuramos aclarar o conceito de racionalidade com base no uso da expressão 'racional', tivemos de nos apoiar sobre uma précompreensão que se encontra ancorada em posicionamentos modernos da consciência. Até o momento, partimos do pressuposto ingênuo de que na compreensão de mundo moderna expressam-se certas estruturas da consciência que pertencem a um mundo da vida racionalizado e por princípio possibilitam uma condução racional da vida. Implicitamente, relacionamos à nossa compreensão de mundo ocidental uma pretensão de universalidade. Para entender o significado dessa pretensão de universalidade, recomenda-se fazer uma comparação com a compreensão de mundo mítica. Em sociedades arcaicas, os mitos cumprem de maneira exemplar a função unificadora própria às imagens de mundo. Ao mesmo tempo, no âmbito das tradições culturais a que temos acesso, eles proporcionam o maior contraste em relação à compreensão de mundo dominante em sociedades modernas. Imagens de mundo míticas estão muito longe de nos possibilitar orientações racionais para a ação, no sentido que as entendemos. No que diz respeito às condições da condução racional da vida no sentido anteriormente apontado, constituem até mesmo uma contraposição à compreensão de mundo moderna. Portanto, na face do pensamento mítico não teriam de se fazer visíveis os pressupostos do pensamento moderno tematizados até o momento (Habermas, 2012a, p. 94-95).

Ora, o que a racionalização cultural-comunicativa permite à modernidade em termos societais-culturais, cognitivo-morais e epistemológico-políticos? No mesmo sentido, o que a falta dela gera, em termos de sociedades-culturas tradicionais? Comecemos pela segunda pergunta. As sociedades tradicionais são marcadas pela férrea 
imbricação entre natureza ou mundo objetivo, sociedade ou cultura e subjetividade, no sentido de que a natureza aparece e é concebida em termos antropomórficos e a sociedade-cultura em termos naturalizados, de modo a subsumirem os indivíduos dentro dessa dupla e correlata estrutura societal-cultural e biológico-espiritual totalizante, que somente pode ser acessada pela magia ou pela religião, posto a natureza ser antropomorfizada e a sociedade-cultura naturalizada. Nesse sentido, as sociedades tradicionais não possuem nem a historicização e a politização da sociedade, nem a tecnicização da natureza e nem, ainda, uma noção fundante de subjetividade reflexiva, contrariamente à modernidade europeia. Com efeito, a naturalização da sociedade significa exatamente sua despolitização, a despolitização do status quo, das instituições e das autoridades político-culturais, o que também significa a consolidação de uma organização institucional dogmática e despótica. No mesmo sentido, a antropomorfização da natureza implica em que ela assuma um sentido mágico-animista, e não, como na modernidade, técnico-instrumental, o que tem como consequência que, nessas mesmas sociedades tradicionais, a natureza, ao possuir um sentido e uma dinâmica diretamente espiritualizados, mágicos, torna-se sobreposta ao ser humano, subsumindo-o. No mesmo diapasão, as sociedades-culturas tradicionais, dadas estas características, impedem, bloqueiam o surgimento de um indivíduo crítico-reflexivo que é independente tanto da natureza quanto da própria sociedade-cultura, como é o caso da subjetividade reflexiva moderna, senão que o esmagam e subsumem no caudal totalizante desse horizonte social-cultural-natural mágico. Por isso, esta estrutura sociocultural, antropológico-ontológica e epistemológico-política das sociedades tradicionais leva a que não exista criticismo social, práxis política e transformação institucional nessas mesmas sociedades, seja por causa da naturalização e despolitização da sociedade-cultura, seja por causa da antropomorfização da natureza, seja, por fim, pela inexistência de uma noção de subjetividade reflexiva, fundante (cf.: Habermas, 2012a, p. 94-141). Por isso a afirmação de Habermas, na passagem citada acima, de que as sociedades-culturas tradicionais não são racionais e nem geram racionalização social.

Em contrapartida, a sociedade-cultura europeia moderna é racional e gera racionalização social, posto que ela é marcada pela gradativa separação entre natureza ou mundo objetivo, sociedade ou cultura e subjetividade. Nesse sentido, a natureza torna-se um campo e um objeto técnico-instrumental, a sociedade-cultura torna-se desnaturalizada e, portanto, politizada, e a subjetividade reflexiva pode, assim, separar- 
se tanto do mundo objetivo quanto dos limites socioculturais, tornando-se, em grande medida, independente deles - independente não no sentido de não possuir nenhum contexto de emergência, mas de posicionar-se exatamente a partir de uma perspectiva formalista e universal que, aliás, é a própria modernidade, gerada por esta. Importante, aqui, é exatamente o fato de que a modernidade, por meio da racionalização culturalcomunicativa, consolida a secularização cultural-institucional como a base fundante dos processos de socialização e de subjetivação. Com a secularização cultural-institucional, a sociedade-cultura, seu status quo, suas autoridades institucionais centrais, seus valores, suas práticas e suas formas de organização etc., tornam-se todas politizadas, posto que desnaturalizadas. Elas passam, por conseguinte, a ser entendidas como uma construção humana em primeira mão, como um produto resultante da própria práxis humana consciente de si mesma, para si mesma, sobre si mesma (cf.: Habermas, 2012a, p. $140-142$, p. 249 , p. 299 , p. $383-384$; Habermas, 2012b, p. 87-115, p. 196, p. 355; Habermas, 2002a, p. 03-25). Aqui, na modernidade, por meio da racionalização cultural-comunicativa, o homem, no coletivo e individualmente, passa a ser o artífice de si mesmo, de seu próprio mundo, seja natural, seja societal-cultural - tudo torna-se profano, historicizado, politizado. É a época da política, da racionalização, da práxis humana.

Ora, aqui aparece em cheio a afirmação habermasiana de que a modernidade europeia é racional e geradora de racionalização social, assim como sua outra e correlata afirmação de que há uma imbricação profunda, a ser desvelada e reforçada e sustentada pelo discurso filosófico-sociológico da modernidade, entre modernização, racionalização, crítica, reflexividade, emancipação e universalismo. Com efeito, em uma sociedade-cultura profana e politizada, caracterizada pela consolidação da subjetividade reflexiva, a validação das instituições, dos sujeitos, dos valores e das práticas socialmente vinculantes já não pode mais acontecer em termos essencialistas e naturalizados, dogmáticos e conservadores, como no caso das sociedades tradicionais, em que há uma imposição centralizada e verticalizada deles. Nas sociedades modernas, a validade objetiva dos valores, das práticas e dos poderes vigentes e instituídos acontece por meio de um processo público de justificação e de discussão-interação em que a racionalidade é tanto a chave da construção do posicionamento dos indivíduos e grupos quanto o fundamento para a aceitação do melhor argumento socialmente cogente. Por isso, como esfera público-política, os indivíduos e grupos sociais 
modernos são obrigados a substituírem fundamentações essencialistas e naturalizadas na esfera público-política e como esfera público-política por argumentos e práticas formais, imparciais, neutros e impessoais, como condição da justificação e do acordo intersubjetivos (cf.: Habermas, 2012a, p. 249, p. 448; Habermas, 2012b, p. 87, p. 141, p. 280, p. 315-316).

Aqui, a racionalização cultural-comunicativa aponta para a necessidade de se usar conceitos formais, não mais vinculados a bases essencialistas e naturalizadas, fomentando e, ao fim e ao cabo, consolidando a racionalidade - nessas suas características de politização-secularização e de procedimentalismo imparcial, neutro, formal e impessoal - como a única base da práxis. Com isso, os indivíduos e os grupos sociais modernos conseguem pensar-agir-fundamentar com base em conceitos totalmente genéricos, substituindo, por exemplo, o conceito de comunidade de sanguecultura pelo conceito de humanidade. Eles pensam-agem-fundamentam, por causa dessa generalidade e dessa abstração, em nome de todos, para todos e por todos, afinal, no exemplo acima, diferentemente da particularidade própria à comunidade de cultura, o conceito de humanidade permite assumir a todos os contextos e, desde eles, a todos os sujeitos epistemológico-políticos (cf.: Habermas, 2012a, p. 148-168, p. 448; Habermas, 2012b, p. 315; Habermas, 1989, p. 143-233). A modernidade europeia é racional e geradora de racionalização social porque substitui bases essencialistas e naturalizadas por racionalização cultural-comunicativa, por politização radical, por diálogo e interação permanentes como os únicos caminhos e meios da validação das normas, das práticas e das instituições, pondo de lado o e prescindindo do dogmatismo; no mesmo sentido, ela substitui a dependência e a férrea imbricação ao contexto, próprios do tradicionalismo e legitimados por este, por formalização, impessoalidade, neutralidade e imparcialidade. Ora, é aqui que a modernidade torna-se autêntico universalismo em termos societais-culturais, antropológico-ontológicos e epistemológico-políticos: dada a centralidade da racionalização cultural-comunicativa, é instituído, na sociedade moderna e a partir dela, o procedimentalismo imparcial, neutro, formal e impessoal como o modo por excelência de método, de práxis e de consciência cognitivo-moral próprias à sociedade moderna. Desse modo, a Europa moderna é uma sociedade-cultura, consciência cognitivo-moral e paradigma normativo descentrados, pós-tradicionais, calcados basicamente na racionalização cultural-comunicativa e dinamizados em termos de procedimentalismo imparcial, neutro, formal e impessoal, o que torna essa mesma 
sociedade-cultura moderna e seus indivíduos e seus grupos socioculturais fundamentalmente universalistas, altamente reflexivos, críticos e emancipatórios (cf.: Habermas, 2012a, p. 142, p. 384-385, p. 587; Habermas, 2012b, p. 87-202; Habermas, 1990b, p. 65-103; Habermas, 1989, p. 61-132).

Aqui chegados, Habermas, com a intenção de associar modernização, racionalização, crítica, reflexividade, emancipação e universalismo, realiza uma dupla estratégica metodológico-programática e epistemológico-política, a saber: separa modernidade cultural e modernização econômico-social, colocando aquela, enquanto esfera puramente normativa, como base ontogenética desta, que aparece como campo basicamente instrumental, lógico-técnico; e passa a conceber a racionalização culturalcomunicativa como tendência geral a todo o gênero humano, como o núcleo comum desse mesmo gênero humano, o que lhe permite a correlata afirmação de que todas as sociedades-culturas podem ser enquadradas a partir da racionalização culturalcomunicativa (podendo também, por conseguinte, utilizar o procedimentalismo imparcial, neutro, formal e impessoal como base do diálogo-práxis intercultural), bem como de que a modernidade-modernização europeia é a primeira sociedade-cultura a alcançar efetivamente esse estágio universal, enquanto racionalização culturalcomunicativa, descentração e procedimentalismo plenos, o que possibilita a associação, no caso de Habermas, entre modernização, racionalização, universalismo e gênero humano, modernização como gênero humano (cf.: Habermas, 2012a, p. 355-357; Habermas, 2012b, p. 202). A pergunta que Habermas se faz é bem direta, relativamente à associação-correlação de modernidade, racionalização, universalismo e gênero humano: a modernidade é uma sociedade-cultura, consciência cognitivo-moral e paradigma epistemológico-político universalistas ou ligados inextricavelmente a um contexto antropológico-ontológico e sociocultural particular? Ela pode assumir a pretensão de universalidade que afirma ou é apenas uma cultura marcada pela centralidade da ciência e, portanto, particularista? (cf.: Habermas, 2012a, p. 109-110). Lembremos que, consoante à tradição filosófica ocidental, a universalidade é a condição do contextualismo e da particularidade, a base ontogenética daquela, assim como a objetividade antropológico-ontológica e epistemológico-moral é a condição da crítica, da reflexividade, da emancipação e da justificação, interrompendo, mas não necessariamente eliminando, o ceticismo, o relativismo e o subjetivismo. Habermas está consciente dessa herança, aceita-a e utiliza-a como critério norteador da construção de 
sua teoria filosófico-sociológica da modernidade. Enfim, a modernidade é universal ou particular, independente do contexto material de que emerge ou presa a ele? Ora, se ela não for universal, independente do contexto material particularizado, então ela não pode ser assumida como guarda-chuva normativo de todas as diferenças, para todas elas, por todas elas.

Já foi dito acima que a modernidade europeia, calcada na e definida pela racionalização cultural-comunicativa, é universalista por fundar e dinamizar o procedimentalismo imparcial, neutro, formal e impessoal - tanto como práxis quanto como método - em termos de base de qualquer processo de legitimação-fundamentação axiológica. Ela seria racional e geradora de racionalização social exatamente na medida em que esse mesmo procedimentalismo, em sua imparcialidade, neutralidade, formalidade e impessoalidade, libertaria os indivíduos e os grupos sociais relativamente ao contexto de que emergem, não no sentido de que seriam indivíduos e grupos sem contexto de gênese e de desenvolvimento, mas sim de que esses mesmos indivíduos e grupos poderiam fundamentar suas normas e suas práticas exclusivamente a partir de valores genéricos, formalistas, e por meio de práticas totalmente impessoais e imparciais. Aqui, instituir-se-ia uma sociedade-cultura e uma consciência cognitivomoral descentradas ou pós-convencionais, isto é, que não necessitariam mais da referência direta a um contexto material-cultural concreto como base da objetividade dos valores, senão que apenas essa generalidade, formalidade, imparcialidade, impessoalidade e neutralidade seriam suficientes para garantir a objetividade e a intersubjetividade de tais valores e práticas vinculantes. Com isso, a modernidade europeia seria universal e consolidaria o universalismo porque, por meio da correlação de racionalização cultural-comunicativa e de procedimentalismo imparcial, neutro, formal e impessoal, embasaria e dinamizaria uma postura societal-cultural e cognitivomoral não-egocêntrica e não-etnocêntrica, altamente promotora da alteridade. É nesse sentido, mais uma vez, que Habermas defende a superioridade da sociedade-cultura europeia moderna em gerar o universalismo epistemológico-moral (em termos do procedimentalismo imparcial, neutro, formal e impessoal) via consolidação da racionalização cultural-comunicativa. Aqui chegados, duas perguntas surgem: primeira, se a modernidade é diretamente universalista, geradora de crítica, reflexividade e emancipação por meio da racionalização cultural-comunicativa, como explicar as suas patologias psicossociais? No mesmo diapasão, como é possível afirmar-se a correlação 
de modernização, racionalização, universalismo e gênero humano, isto é, a modernidade como ápice evolutivo do gênero humano em termos de sociedade-cultura e consciência cognitivo-moral descentradas, pós-convencionais?

Como é possível, em relação à primeira pergunta, afirmar-se, por um lado, a universalidade da modernidade e, por outro, responder-se às suas graves patologias psicossociais? Não fazem elas, universalidade e patologias, parte de um mesmo horizonte totalizante e unidimensional como racionalização, por meio desta? Habermas responde: não. É necessário distinguir, na reconstrução do processo de modernização ocidental via discurso filosófico-sociológico da modernidade, entre modernidade cultural (e, aqui, racionalização cultural-comunicativa) e modernização econômicosocial (e, aqui, racionalidade instrumental, lógico-técnica), o que também significa a distinção entre mundo da vida e sistema social (ou sistemas sociais - no caso, em particular, mercado capitalista e Estado burocrático-administrativo como os dois grandes sistemas sociais modernos). A modernidade cultural é, para Habermas, a base ontogenética do processo de modernização como um todo: foi por meio dela que nos tornamos modernos, que nossa sociedade-cultura tornou-se moderna, naquelas características acima definidas. E é a partir dela que a modernização econômico-social foi gerada, dela tendo-se separado ao longo de seu desenvolvimento. Com efeito, para Habermas, a modernidade cultural, em termos de racionalização cultural-comunicativa, ocasiona um duplo efeito em termos socioculturais e epistemológico-políticos. $\mathrm{O}$ primeiro, que já foi explicitado acima, consiste na desnaturalização e na politização da sociedade-cultura, de suas instituições, valores, práticas, autoridades e sujeitos epistemológico-políticos, com a consolidação da secularização cultural-institucional e da subjetividade reflexiva e fundante, basicamente politizadas e politizantes. O segundo, caudatário desse, é a desconstrução de uma sociedade totalizante e unidimensional, fundada em apenas um princípio e em apenas uma base normativa em termos de integração sociocultural e de fundamentação axiológica. A modernidade já não é mais uma sociedade-cultura imbricada de modo férreo em todas as suas partes e nem funciona com base em apenas um único e exclusivo princípio normativo em todas as suas esferas e por todos os seus sujeitos. Habermas fala, nesse diapasão, de que a modernização da sociedade significa a diferenciação das esferas de valor próprias à sociedade, com a consequente institucionalização dos sistemas sociais e das culturas de especialistas no que diz respeito a cada área da sociedade-cultura (cf.: Habermas, 2012a, 
p. 140-141, p. 299, p. 587; Habermas, 2012b, p. 263, p. 521). Nesse sentido, a economia, o Estado, a escola, a arte, a religião etc. possuem campos específicos, com princípios, práticas, dinâmicas e sujeitos correlatos, que não funcionam ou não servem nos outros campos, que são próprios e particulares a cada campo da reprodução social. Aqui podemos situar a emergência dos sistemas sociais modernos, no caso o Estado e o mercado em termos de modernização econômico-social, cada um deles centralizando, monopolizando e, com isso, individualizando seu campo de atuação em termos societais. Diferentemente das sociedades tradicionais, centralizadas, totalizantes e unidimensionais, dotadas de um único principio e de única base de integração e de fundamentação, a sociedade europeia moderna é, também aqui, descentrada e plural no que diz respeito aos princípios e às práticas de integração e de fundamentação, no sentido de que cada área da vida social é particularizada e diferenciada, exigindo consequentemente princípios, bases e sujeitos epistemológico-políticos correlatos e, por isso mesmo, singulares - isso, a diferenciação das esferas de valor sociais, na modernidade, é consequência da racionalização cultural-comunicativa.

Portanto, a modernidade-modernização ocidental é separada, por Habermas, em um duplo, ainda que interligado, processo evolutivo-constitutivo: a modernidade cultural ou mundo da vida e a modernização econômico-social ou sistemas sociais modernos (cf.: Habermas, 2012a, p. 588-591; Habermas, 2012b, p. 216-217). A modernidade cultural, primigênia ontogeneticamente falando em relação à modernização econômico-social, é uma esfera fundamentalmente normativa e é ela que serve de base à construção do paradigma normativo da modernidade enquanto correlação de modernização, racionalização e universalismo. A modernização econômico-social é uma esfera fundamentalmente lógico-técnica, de racionalidade instrumental, não-normativa e não-política (cf.: Habermas, 2012b, p. 424). Por meio dessa separação, que é a um só tempo metodológico-programática e político-normativa, Habermas pode defender (contra Weber, Adorno \& Horkheimer e Marcuse) não apenas que não existe um único, totalizante e unidimensional processo de racionalização e que, em verdade, a modernidade dual começa como racionalização cultural-comunicativa, totalmente revolucionária e emancipatória, como um novo (e revolucionário e emancipatório, porque universal) estágio da evolução humana (cf.: Habermas, 2012b, p. 540), senão também que as patologias psicossociais geradas pela modernização ocidental têm sua causa na e por parte da modernização econômico-social (cf.: 
Habermas, 2012b, p. 551-553). Com efeito, esta, marcada por sistemas sociais lógicotécnicos, instrumentais, não-políticos e não-normativos, tem a tendência de, vez por outra, ultrapassar seu campo de atuação e adentrar, colonizar, desde um ponto de vista lógico-técnico, instrumentalizado e instrumentalizante, a esfera própria ao mundo da vida, que é fundamentalmente normativa - o conceito habermasiano de colonização do mundo da vida é construído para representar, para significar esse processo de instrumentalização causado pelos sistemas sociais no mundo da vida (cf.: Habermas, 2012b, p. 330-331, p. 355). Com isso, a modernidade cultural é eximida da irracionalidade que, por outro lado, é percebida como tendo sua causa no desenvolvimento desmesurado e sem controle do mercado capitalista e do Estado burocrático-administrativo. De todo modo, essa diferenciação metodológicoprogramática e político-normativa entre modernidade cultural e modernização econômico-social, via discurso filosófico-sociológico da modernidade calcado em uma noção de modernidade dual, serviu diretamente para duas tarefas basilares de uma teoria da modernidade europeia fiel à tradição filosófico-sociológica ligada à correlação de modernidade, universalismo e gênero humano: primeira, reafirmar a modernidade cultural como efetivo universalismo; segunda, apontar para o fato de que as patologias institucionais-societais modernas são causadas pelos sistemas sociais da modernidade ocidental, no caso o mercado e o Estado. A modernidade cultural, com isso, sai ilesa e sempre pode afirmar-se como inocente em relação a qualquer acusação de irracionalidade-violência que é feita contra a modernidade-modernização. A culpa é sempre da modernização econômico-social. É por isso que Habermas defende de modo enfático e contundente que, por causa da separação entre modernidade cultural e modernização econômico-social, e por causa do sentido primigênio ontogeneticamente falando daquela em relação a esta, a modernidade cultural é autorreflexiva e autocorretiva desde dentro, de si mesma e para si mesma, mantendo seu apelo e sua vinculação universalistas e podendo sustentar-se como tal (cf.: Habermas, 2012a, p. 227). No mesmo sentido, seja por causa de a modernidade cultural ser a base ontogenética da modernização econômico-social (situando esta no horizonte normativo mais amplo daquela), seja pela separação entre uma e outra, a modernidade cultural, sob a forma do mundo da vida, permite a crítica e a reflexividade sociais, assim como a emancipação política, na medida em que serve de critério paradigmático tanto para se avaliar os impactos dos sistemas sociais na vida cultural-normativa cotidiana (o mundo da vida), seja para se pensar a reorientação ou o refreamento dos sistemas sociais em 
sua tendência à colonização do mundo da vida, o que permite afirmar-se, mais uma vez, o sentido revolucionário em termos político-culturais e epistemológico-normativos da modernidade cultural (cf.: Habermas, 2012b, p. 403-404, p. 410; Habermas, 2003b, p. $83)$.

Ora, como se percebe ao longo do texto, há uma ênfase muito grande, no caso de Habermas, na ideia de que a modernidade é autêntico universalismo, totalmente adequado à época pós-metafísica, em que fundamentações essencialistas e naturalizadas já não são mais a base da objetividade antropológico-ontológica e epistemológicomoral, e nem do acordo político-normativo em termos intersubjetivos (ou até do diálogo-práxis intercultural). Por isso, Habermas dá, agora, depois dessa especificação do processo de modernização ocidental em seu sentido dual e, a partir dele, da diferenciação do que é modernidade cultural e do que é modernização econômicosocial, um passo totalmente surpreendente e definitivo em sua teoria da modernidade, a saber, ele não apenas correlaciona modernização, racionalização e universalismo, senão que também aponta para a imbricação de modernização, racionalização, universalismo $e$ gênero humano, modernidade-modernização como gênero humano, a partir da ideia de que a racionalidade cultural-comunicativa, se por um lado encontrou seu apogeu em termos de modernidade europeia, por outro constitui o próprio núcleo ontogenético da espécie humana, na medida em que a fala-comunicação-razão é o que nos caracteriza de modo mais fundamental. No caso da modernidade, ela apenas representa a consolidação e a maturação desse passo evolutivo rumo à centralidade da racionalização culturalcomunicativa em termos evolutivos e constitutivos, um processo que aconteceu antes nela em relação às outras sociedades; entretanto, a racionalização cultural-comunicativa é um processo que faz parte em maior ou menor medida da constituição e da evolução de todas as sociedades-culturas, embora mais destacado, maturado e intensificado na Europa moderna. Essa ideia, muito surpreendente e impactante para a teoria da modernidade, pode ser percebida em cheio na passagem que segue, por parte de Habermas:

Se não delineamos o racionalismo ocidental a partir da perspectiva conceitual da racionalidade propositada e da dominação do mundo e, mais que isso, se tomamos como ponto de partida a racionalização de mundo descentralizada, impõem-se as seguintes perguntas: onde se expressa um acervo formal de estruturas universais da consciência? Não é, afinal, nas esferas de valor culturais desenvolvidas de maneira obstinada sob os parâmetros valorativos abstratos de verdade, correção 
normativa e autenticidade? O que constitui, afinal, o patrimônio da "comunidade dos homens de cultura", presente como ideia reguladora? Não são as estruturas do pensamento científico, das noções jurídicas e morais pós-tradicionais e da arte autônoma - tal como formadas no âmbito da cultura ocidental? A posição universalista não precisa negar o pluralismo e a incompatibilidade das marcas históricas da "condição cultural própria ao ser humano", mas percebe que essa multiplicidade das formas de vida está restrita aos conteúdos culturais e afirma que toda cultura, se fosse o caso de alcançar um certo grau de "conscientização" ou de "sublimação", teria de compartilhar certas qualidades formais da compreensão de mundo moderna. A assunção universalista refere-se, portanto, a algumas características estruturais e necessárias próprias a mundos da vida modernos. Por outro lado, quando tomamos essa concepção universalista como coerciva somente para nós, o relativismo que se refuta no plano teórico acaba retornando no plano metateórico. Não creio que um relativismo de primeiro ou de segundo grau possa conciliar-se com o âmbito conceitual em que Weber situa a problemática da racionalização. No entanto, Weber faz restrições relativistas. Elas se devem a um motivo que só teria deixado de existir se Weber não tivesse atribuído o que há de especial no racionalismo ocidental a uma peculiaridade cultural, e sim ao modelo seletivo que os processos de racionalização assumiram sob as condições do capitalismo moderno (Habermas, 2012a, p. 325-326; os destaques são de Habermas).

A passagem citada diz respeito ao fato de Weber, no entender de Habermas, ter assumido o relativismo ou premissas relativistas quando de seu estudo do processo de modernização ocidental. Para além dessa interpretação e discussão sobre o relativismo weberiano, o que nos interessa é a resposta dada por Habermas, aqui, no que se refere à compreensão da modernidade europeia enquanto universalismo epistemológico-moral. Porque, na passagem, o que aparece de modo explícito é que somente somos relativistas, no entendimento do processo de modernização ocidental, se olhamos para a modernização econômico-social, isto é, para a racionalidade instrumental e lógicotécnica, bem como para os sistemas sociais modernos, Estado e mercado, que efetivamente são as principais estruturas-sujeitos instrumentais da modernidademodernização e, como dissemos acima, os verdadeiros causadores das patologias psicossociais modernas. Porém, quando lançamos um olhar para essa estilização da modernidade cultural feita por Habermas, perceberemos, como ele quer, seu sentido e sua constituição direta e pungentemente universalistas, inclusive e porque, como vimos dizendo, a racionalidade cultural-comunicativa é a base da constituição, da reprodução, do desenvolvimento e da evolução do gênero humano ao longo do tempo e sobre si 
mesmo. Portanto, somente seríamos relativistas - e pessimistas - no que diz respeito à modernidade europeia se focarmos nela de modo unidimensional, enfatizando apenas a modernização econômico-social, esta sim um fenômeno que é próprio apenas à Europa moderna (ao contrário da modernidade cultural, da racionalização culturalcomunicativa, que, se é verdade que alcançou sua maturação enquanto universalismo na Europa moderna, por outro lado é parte constitutiva e definidora de toda e qualquer sociedade-cultura humana, permitindo-nos falar na racionalização cultural-comunicativa como o núcleo comum, ontogenético do e ao gênero humano); nesse sentido, quando lançamos um olhar para a modernidade cultural e, nela, para a racionalidade culturalcomunicativa, perceberemos seu sentido fundamentalmente crítico-reflexivo, revolucionário e emancipatório, entre outras coisas pela secularização culturalinstitucional e pela consolidação da subjetividade reflexiva, pela diferenciação das múltiplas esferas de valor sociais e sua consequente institucionalização, assim como para o procedimentalismo imparcial, neutro, formal e impessoal, que dinamiza e é dinamizado por uma estrutura societal-cultural e por uma consciência cognitivo-moral descentradas, pós-convencionais.

Ora, em primeiro lugar, a modernidade é universal porque elevou a ponto fundante exatamente a racionalização cultural-comunicativa secularizada, desnaturalizada, politizada, que consolida esse mesmo procedimentalismo imparcial, neutro, formal e impessoal como método-práxis da fundamentação intersubjetiva. Como dissemos, entretanto, a racionalidade cultural-comunicativa faz parte de todas as sociedades-culturas humanas, posto que elas são e nós seres humanos somos constituídos, definidos e moldados pela fala-práxis: muito mais do que o trabalho ou qualquer outro princípio antropológico-ontológico, é a linguagem que nos define de maneira fundamental, a nós, todos os seres humanos, todas as sociedades-culturas humanas. De mais a mais, todas as sociedades-culturas humanas fundam seus correlatos processos de socialização e de subjetivação na forte objetividade antropológicoontológica e epistemológico-moral de seus valores, de suas práticas, de suas instituições e de seus sujeitos. Ora, como se pode fundar essa mesma objetividade e torná-la vinculante sócio-culturalmente? Exatamente por meio da racionalidade culturalcomunicativa, em que cada sociedade-cultura institucionaliza e realiza ao longo do tempo um processo permanente e direto de inculcação e de justificação de seus valores, práticas, instituições e autoridades. É a fala-práxis, também aqui, que aspira à 
objetividade, que a encampa, que a legitima e que a fomenta sócio-culturalmente; é a fala-práxis, portanto, que caracteriza todas as sociedades-culturas humanas, sua reprodução, sua estabilidade e sua evolução ao longo do tempo. Note-se, de todo modo, mais uma vez, o apelo da passagem de Habermas, acima citada: não podemos ser relativistas e isso nem é possível pelo fato de que existe um núcleo duro ao gênero humano, que é constituído e significado exatamente pela racionalidade culturalcomunicativa. Como dissemos acima, Habermas acredita que ela encontrou sua maturação e sua consistência pela primeira vez em termos de modernidademodernização europeia (e dali para outras sociedades-culturas), mas em princípio a racionalização cultural-comunicativa, enquanto núcleo comum ao gênero humano, enquanto base ontogenética desse mesmo gênero humano em seu processo de constituição, desenvolvimento e evolução ao longo do tempo, é parte fundamental de todas as sociedades-culturas. Por isso sua afirmação de que apenas a modernização econômico-social, sob a forma dos sistemas sociais instrumentais e lógico-técnicos, como o Estado burocrático-administrativo e o mercado capitalista, é que constitui de modo específico à modernidade europeia, embora, repetimos, a modernidade cultural, a racionalização cultural-comunicativa, que se faz presente em todas as sociedadesculturas em maior ou menor intensidade, que constitui diretamente todo o gênero humano, aglutinando-o, tenha encontrado sua maturação e seu desenvolvimento pleno na Europa moderna e sob a forma de modernização.

Com isso, a teoria da modernidade, uma vez afirmada a universalidade da modernidade cultural europeia sob a forma da correlação de racionalização culturalcomunicativa e procedimentalismo imparcial, neutro, formal e impessoal, pode afirmar sem nenhum problema que, sim, efetivamente todas as sociedades-culturas podem ser enquadradas por um universalismo epistemológico-moral corretamente construído, posto que (a) a racionalidade cultural-comunicativa é o núcleo ontogenético das sociedades-culturas humanas e (b) todas estas culturas-sociedades humanas partem da objetividade de seus valores, práticas e sujeitos fundantes, realizando um processo público de legitimação, inculcação e fomento deles - o que significa que todas elas são racionais e usam a racionalização social como base de sua legitimação, de sua constituição e de seu desenvolvimento ao longo do tempo. Logo, existem pontos comuns entre as sociedades-culturas humanas que permitem a um paradigma epistemológico-moral universalista enquadrá-las e orientar o diálogo-práxis 
intercultural, intersubjetivo. No mesmo diapasão e em consequência, esse papel e essa práxis cabem e são fornecidos pela modernidade cultural europeia como autêntico universalismo, como ápice da evolução do gênero humano (e superior, portanto, aqui, nesse quesito do universalismo, ao tradicionalismo em geral). De antemão, para o paradigma normativo da modernidade, é possível o enquadramento, a crítica, a avaliação e a orientação das sociedades-culturas humanas particulares, porque existe unidade no gênero humano e sob a forma de racionalidade cultural-comunicativa, um papel e uma práxis que cabem à perfeição ao paradigma normativo da modernidade, na medida em que ele é marcado pela correlação de racionalização cultural-comunicativa e/como procedimentalismo imparcial, neutro, formal e impessoal. Diz Habermas:

\begin{abstract}
É certo que, por sua referência totalizante, as imagens de mundo estão eximidas da dimensão em que faz sentido um julgamento segundo critérios de verdade; até mesmo a escolha de critérios segundo os quais se julga a verdade em enunciados pode depender do contexto de uma imagem de mundo que seja relativo a conceitos básicos. Não decorre disso, porém, que se possa entender a própria ideia de verdade de maneira particularista. Seja qual for o sistema lingüístico que escolhamos, sempre partimos intuitivamente do pressuposto de que a verdade seja uma pretensão universal de validade. Quando um enunciado é verdadeiro, merece o assentimento universal, tenha ele sido formulado nesta ou naquela língua. Portanto, [...] imagens de mundo não só podem ser comparadas entre si sob os pontos de vista da coerência, profundidade, economia, completude etc. - pontos de vista como que estéticos e indiferentes à verdade -, mas também sob o ponto de vista da adequação cognitiva. A adequação de uma imagem de mundo linguisticamente articulada é uma função dos enunciados verdadeiros que sejam possíveis nesse sistema lingüístico (Habermas, 2012a, p. 119-120. Cf., ainda: Forst, 2010, p. 334-345).
\end{abstract}

Note-se a afirmação de Habermas, que corrobora o que dissemos acima: as diferenças entre as sociedades residem apenas ao nível dos conteúdos, o que também significa que o que há de contextual e particularizado a cada cultura-sociedade humana são exatamente seus conteúdos axiológicos. Porém, as estruturas e a práxis da fundamentação são a mesma, isto é, a objetividade axiológica, o diálogo-práxis como fundamentação, a referência ao mundo cotidiano e natural etc. São todos pontos comuns que provam, mais uma vez, tanto a possibilidade do diálogo-práxis intercultural desde a racionalização quanto, com isso, a universalidade da modernidade e, aqui, a correlação de modernização, racionalização, universalismo e gênero humano, modernidademodernização como ápice do desenvolvimento do gênero humano, posto que autêntico 
universalismo. Por isso, se todas as sociedades-culturas são racionais, estão embasadas na e dependentes da racionalização cultural-comunicativa em maior ou menor medida, então a sociedade-cultura que alcançou a maturação dessa mesma racionalização cultural-comunicativa, a Europa moderna sob a forma de procedimentalismo imparcial, neutro, formal e impessoal (como a maturação da racionalização cultural-comunicativa), tem condições de intermediar e de orientar esse mesmo diálogo-práxis intersubjetivo e intercultural - o que reforça a correlação de modernização, racionalização, universalismo e/como gênero humano. No mesmo sentido, tais pontos provam exatamente que a evolução humana vai do tradicionalismo à modernização, começa como tradicionalismo enquanto dogmatismo e contextualismo-particularismo e chega à modernidade como racionalização cultural-comunicativa e universalismo, modernidademodernização como superação do tradicionalismo. Ora, a evolução humana é superação do tradicionalismo e consolidação da modernidade-modernização? Como é possível provar isso? Habermas responde: por meio da psicologia moral em sua reconstrução do processo de desenvolvimento de nossa consciência cognitivo-moral (assim como por meio da análise sociológico-antropológica em sua separação entre sociedades modernas e sociedades tradicionais, bem como por meio da noção filosófica, própria à tradição filosófica europeia, de que o universalismo é a condição do particularismo e, aqui, de que existem sociedades-culturas universais - como é o caso da Europa moderna na visão de Hegel e do próprio Habermas). Com efeito, é daqui, da psicologia moral, que ele retira os conceitos de descentração e consciência cognitivo-moral pós-convencional enquanto as características-chave da moderna visão de mundo e do moderno sujeito epistemológico-político. A descentração da sociedade-cultura e da consciência cognitivo-moral, como resultado da correlação de racionalização cultural-comunicativa e de individuação forte próprias à sociedade moderna, consolida a perspectiva universalista enquanto procedimentalismo imparcial, neutro, formal e impessoal, em que os indivíduos e grupos sociais do horizonte da modernidade assumem um posicionamento vital não-egocêntrico e não-etnocêntrico em relação a si mesmos, às tradições e à alteridade de um modo mais geral. É nesse contexto que a modernidade é uma sociedade-cultura pós-tradicional e consolida o nível pós-convencional ou descentrado da consciência, marcado pela autonomia, pela reflexividade, pela formalização e pelo posicionamento universal relativamente aos valores, às práticas e aos sujeitos epistemológico-políticos de um modo geral: aqui, todos os processos de fundamentação intersubjetiva são definidos e perpassados pela racionalização, bem 
como orientados por essa postura não-egocêntrica e não-etnocêntrica possibilitada pela modernidade-modernização enquanto sociedade-cultura pós-tradicional, descentrada, e expressa em termos de procedimentalismo imparcial, neutro, formal e impessoal (cf.: Habermas, 2012a, p. 142; p. 168; Habermas, 1989, p. 49-58). Isso prova, mais uma vez, a superioridade da modernidade-modernização, dada a centralidade, nela, da racionalização cultural-comunicativa, superioridade que se manifesta sob a forma desse universalismo epistemológico-moral como procedimentalismo imparcial, neutro, formal e impessoal, e como consciência cognitivo-moral não-egocêntrica e não-etnocêntrica. $O$ paradigma normativo da modernidade, por conseguinte, nessa correlação de modernização, racionalização, universalismo e gênero humano, nessa correlação de racionalidade cultural-comunicativa e procedimentalismo imparcial, neutro, formal e impessoal, assim como nessa correlação de sociedade-cultura e de consciência cognitivo-moral descentradas ou pós-convencionais, torna-se o guarda-chuva normativo de todas as diferenças, para todas elas, por todas elas, a condição fundante da crítica, da reflexividade, da emancipação e até do diálogo-práxis intercultural.

2. O colonialismo como teoria da modernidade: repensando o discurso filosófico-sociológico sobre a modernização ocidental a partir da categoria do colonialismo

O discurso filosófico-sociológico da modernidade, no caso de Habermas, teve por objetivo basilar a reconstrução do processo de gênese, de constituição e de desenvolvimento da modernidade europeia, no sentido de apresentá-la como universalidade, assumindo, para isso, algumas estratégias metodológico-programáticas e pré-juízos epistemológico-políticos fundamentais, a saber: a autorreferencialidade, a endogenia e a auto-subsistência do desenvolvimento da modernidade como um processo interno, um esforço de si por si mesma; a diferenciação e a contraposição com o outro da modernidade, com o tradicionalismo em geral, que partiam da e afirmavam a superioridade da sociedade-cultura e da consciência cognitivo-moral modernas em termos de racionalização; a separação entre modernidade cultural e modernização econômico social, a primeira enquanto esfera puramente normativa e condição ontogenética desta, a segunda como esfera basicamente instrumental, lógico-técnica, e verdadeira causa das patologias psicossociais das e nas sociedades modernas; a correlação de modernização, racionalização, universalismo e gênero humano, com os 
argumentos de que a modernidade cultural europeia é autêntico universalismo epistemológico-moral e de que ela é o ápice do gênero humano como superação do tradicionalismo e consolidação da moderna visão de mundo universalista. $\mathrm{O}$ discurso filosófico-sociológico da modernidade é um discurso da modernidade sobre si mesma e por si mesma e, não obstante, (a) parte da contraposição com o outro da modernidade (que está fora dela), com a consequente superioridade da modernidade em relação ao tradicionalismo em geral (embora este outro da modernidade, ao estar fora dela, não ser analisado por esse discurso filosófico-sociológico endógeno e autorreferencial), bem como (b) correlaciona modernização, racionalização, universalismo e gênero humano, modernização como gênero humano, de modo (c) a tornar essa mesma modernidade cultural europeia no guarda-chuva normativo das diferenças e por elas, bem como condição paradigmática da crítica social, da práxis política e do diálogo intercultural. Trata-se, portanto, de um discurso filosófico-sociológico da modernidade sobre si mesma, para si mesma e por si mesma, mas que, ao fim e ao cabo, é também um discurso sobre o gênero humano por si mesmo e para si mesmo! Trata-se de um discurso filosófico-sociológico sobre a constituição da modernidade europeia desde si mesma que, ao fim e ao cabo, percebe-se triunfantemente como o discurso do próprio gênero humano sobre si mesmo, a partir da ideia de que o processo de evolução humana (inclusive a psicologia moral utilizada provou isso) consiste na superação do tradicionalismo pela moderna visão de mundo e pela moderna consciência cognitivomoral. O resultado do discurso filosófico-sociológico da modernidade é, com isso, o gênero humano, que se confunde diretamente com a própria modernidade cultural. No mesmo sentido, não vimos uma única vez, na teoria da ação comunicativa de Habermas (como de resto nas teorias da modernidade europeia de um modo geral), a menção ao colonialismo. Habermas até utiliza o termo colonização do mundo da vida, como dissemos na primeira parte, mas remetendo-o diretamente às patologias geradas pelo mercado e pelo Estado em termos de racionalidade instrumental, portanto como um fato próprio à modernização econômico-social europeia (ou como um fato próprio à modernização econômico-social em geral), e não ao fenômeno da negação e da conquista simbólico-materiais das sociedades-culturas dominadas pela Europa moderna universal - aqui, a colonização do mundo da vida refere-se às patologias próprias à sociedade moderna em primeira mão e em termos de racionalização instrumental (cf.: Habermas, 2012b, p. 355). 
Nesse sentido, nos perguntamos: é consistente um tal discurso filosóficosociológico que, não obstante conceber o processo de modernização desde uma perspectiva interna, endógena, autorreferencial e auto-subsistente, pode tanto partir da contraposição com o e da inferioridade do outro da modernidade quanto, ao seu final, assumir-se como o ápice do gênero humano, servindo como base paradigmática não apenas para a Europa por si mesma, mas também para o outro da modernidade que ela de antemão excluiu e diminuiu? É realmente inovadora a separação entre modernidade cultural e modernização econômico-social, que não apenas concebe a primeira como totalmente normativa e a segunda como totalmente lógico-técnica, senão que também assume a primeira como pura e santa, ao passo que entende a segunda como a causa de todas as patologias em termos de modernização, eximindo a modernidade cultural e condenando a modernização econômico-social? Por que, além disso, o colonialismo não é mencionado como parte fundante da própria teoria da modernidade? É possível que o paradigma normativo da modernidade seja crítico, reflexivo e emancipatório por si mesmo e sobre si mesmo, servindo também como o guarda-chuva normativo por excelência de todas as diferenças, para todas elas e por todas elas, a partir de tal diferenciação entre modernidade e o outro da modernidade e entre modernidade cultural e modernização econômico-social? Para responder a isso, queremos enfatizar que a teoria da modernidade de Habermas, ao assumir essas três premissas - contraposição ao outro da modernidade; endogenia, autorreferencialidade e auto-subsistência do discurso filosófico-sociológico, mas universalismo e gênero humano como seu resultado final; separação entre cultura e civilização material -, sofre de uma cegueira históricosociológica que põe por terra, que deslegitima sua pretensão de universalidade, sua auto-afirmação como o guarda-chuva normativo das diferenças e, finalmente, seu potencial crítico, reflexivo e emancipatório. Senão vejamos.

Comecemos pela nossa pergunta mais importante? Por que o colonialismo não aparece na teoria da modernidade de Habermas? Em nossa compreensão, ele não aparece pelo fato de que apontaria para a intersecção e mútua dependência de e entre modernidade cultural e modernização econômico-social. Com efeito, o colonialismo não é nem apenas normativo-simbólico ou político-cultural e nem apenas material, mas a conjunção de ambas as dimensões. Ele é, portanto, simbólico, normativo, político, cultural e material concomitantemente. Em verdade, diríamos mais: a base fundante, ontogenética do colonialismo é cultural, normativa, política: há de, primeiramente, 
negar-se o outro em termos simbólico-normativos para, depois, instrumentalizá-lo materialmente, politicamente. No mesmo diapasão, a colonização, nesse sentido que a ela estamos dando, é gradativamente a destruição e substituição da sociedade-cultura colonizada pela sociedade-cultura colonizadora, quando não a destruição completa daquela por esta. De todo modo, aqui está, em nossa compreensão, o ponto basilar para o colonialismo não aparecer nas teorias da modernidade como parte constitutiva fundamental do próprio processo de modernização ocidental ou europeu: ele volta a interligar modernidade cultural e modernização econômico-social, cultura e civilização material em um bloco civilizacional unitário e dependente. Aqui, a cultura legitimaria exatamente a progressão totalizante, unidimensional e colonizatória da modernidade em relação ao outro da modernidade. Por isso mesmo, se devemos falar em modernização ocidental como um conceito abrangente e unitário que abarca tanto a modernidade central quanto a modernidade periférica, tanto as metrópoles quanto as colônias, então não podemos em absoluto silenciar sobre ou apagar o colonialismo, silenciar sobre ou apagar a correlação e mútua dependência entre modernização e colonialismo, modernização central e modernização periférica. Nesse caso, a compreensão da modernidade-modernização ocidental, por Habermas, está equivocada demais, seja em seu ponto de partida, seja em seu ponto de chegada: se é relativa apenas à Europa, como nós a entendemos, então não faria sentido nem a comparação-contraposição com o tradicionalismo em geral e nem, ao fim, a correlação de modernização, racionalização, universalismo e gênero humano, modernização como gênero humano, que colocaria a modernidade europeia como ápice civilizacional e cultural, como apogeu do gênero humano enquanto superação do tradicionalismo e consolidação da moderna sociedadecultura e da moderna consciência cognitivo-moral; se ela se refere à modernização ocidental em um sentido mais amplo (envolvendo, aqui, modernidade central e modernidade periférica, modernização e colonialismo), então o colonialismo deveria ser colocado como base fundante, parte constitutiva fundamental e consequência direta da própria constituição da modernidade naquela correlação de modernidade cultural, modernização econômico-social e colonialismo. Em ambos os casos, o colonialismo seria um dos pontos centrais de uma teoria da modernidade que quer pensar não apenas o sentido da modernização central - primeiro a modernidade-modernização europeia e, depois, o padrão evolutivo das sociedades industrializadas desenvolvidas -, mas também uma perspectiva epistemológico-moral universalista em termos de guarda- 
chuva normativo das diferenças, para elas e por elas mesmas, e em termos de diálogopráxis intercultural.

No caso de Habermas, o silenciamento sobre o e o apagamento do colonialismo de sua teoria da modernidade europeia e, correlata a isso, sua separação entre modernidade cultural e modernização econômico-social, permitem-lhe, com uma só escolha metodológico-paradigmática que é também um pré-conceito político-normativo, responder a três desafios próprios à teoria social crítica, que lhe foram legados pelos seus predecessores: (a) a formulação de um conceito dual de modernidade, dependente em alguns casos (a modernidade cultural como base ontogenética da modernização econômico-social), independente em outros (a modernidade cultural como independente relativamente às patologias psicossociais próprias à modernização econômico-social), que supera a perspectiva unidimensional de Marx, Weber e, principalmente, Adorno, Horkheimer e Marcuse, calcada, no entender de Habermas, na modernidademodernização instrumental, lógico-técnica (aqueles não viram ou não afirmaram a modernidade cultural); (b) a retomada de uma concepção de modernidade (no caso, a modernidade cultural) enquanto normatividade e universalismo, possibilitadas via racionalização cultural-comunicativa, capaz de autorreflexividade, auto-crítica, autocorreção, por causa exatamente daquela separação entre cultura e civilização material, modernidade cultural e modernização econômico-social; e, por fim, (c) a consequente correlação de modernidade, racionalização, universalismo e gênero humano, tanto por causa dessa separação entre modernidade cultural e modernização econômico-social, que purifica a primeira e problematiza apenas a segunda, quanto por causa da pressuposição de que a racionalização cultural-comunicativa é tendência comum, núcleo comum ao gênero humano, à espécie humana, não obstante as diferenciações socioculturais próprias a cada contexto - a racionalização cultural-comunicativa como estrutura comum à constituição, ao desenvolvimento e à evolução da espécie humana.

O colonialismo não pode ser introduzido na teoria da modernidade porque ele quebraria o encanto relativamente à modernidade cultural: ela já não apareceria como pura, ingênua e santa, senão que vinculada materialmente, como, de resto, qualquer outra posição antropológico-ontológica e sociocultural. Uma sociedade é um horizonte simbólico-material completo, em que essa diferenciação entre cultura e civilização material, que não é apenas metodológica, mas escolha política, não se sustenta, não podendo, por isso mesmo, ser afirmada como a condição do próprio universalismo. No 
mesmo sentido, a separação entre modernidade cultural e modernização econômicosocial, no caso da teoria da modernidade de Habermas, é conditio sine qua non da própria viabilidade da teoria, de sua proposta, de seus diagnósticos e de suas críticas. Explicamos: na teoria da modernidade de Habermas - como também no grande leque das teorias filosófico-sociológicas da modernidade europeia sobre si mesma - a separação entre modernidade cultural e modernização econômico-social (ou, pelo menos, a hiper-valorização e sublimação da cultura moderna e sua ligação direta ao universalismo) e o silenciamento-apagamento do colonialismo têm de ser a base fundamente da própria construção teórico-política. Essa dupla escolha, política e metodológica, se quer assumir a modernidade como autêntico universalismo, como guarda-chuva normativo de todas as diferenças, para todas elas e por todas elas, como, ainda, a condição da crítica, da reflexividade e da emancipação, necessita purificar sua base normativa, depurá-la de qualquer resquício ou ameaça de degeneração, de irracionalidade. Ora, a separação entre modernidade cultural e modernização econômico-social e o silenciamento-apagamento do colonialismo obedecem a essa lógica e têm como foco a depuração do paradigma normativo da modernidade como puro e santo universalismo epistemológico-moral. Por meio de ambas, qualquer crítica à modernização pode ser rebatida, por parte do paradigma normativo da modernidade, com a resposta - muito freqüente em Habermas, aliás - de que se trata de um problema relativo à modernização econômico-social, à racionalidade instrumental e lógicotécnica, mas não à modernidade cultural e à racionalização cultural-comunicativa.

Com efeito, conforme mencionamos acima, Habermas afirma que uma das características fundamentais da modernidade cultural europeia é sua autorreflexividade, sua auto-crítica, sua capacidade de auto-correção e de auto-reconstrução. Ela consegue perceber-se em suas potencialidades e problemas e, por isso, pode corrigir-se. Ora, é isso que lhe mantém esse sentido emancipatório e também universalista: na modernidade, há politização e individuação aceleradas e consolidadas, isto é, todos os problemas sociopolíticos, epistemológico-normativos e antropológico-ontológicos, dada a centralidade da racionalidade cultural-comunicativa, aparecem sempre e pungentemente na esfera público-política, não podendo ser velados e justificados ideologicamente - há, por assim, dizer, por causa da centralidade da racionalidade cultural-comunicativa, um criticismo social generalizado e permanente; no mesmo diapasão, essa capacidade autorreflexiva, auto-corretiva e auto-reconstrutiva a 
impulsionam sempre e sempre, e de modo pungente, a uma práxis emancipatória sobre si mesma e mais além, encampando sempre esses ideais universalistas próprios ao gênero humano e em nome dele, que o procedimentalismo imparcial, neutro, formal e impessoal consolida e legitima. Note-se, nesse último caso, a própria ênfase em um procedimentalismo neutro, imparcial, formal e impessoal como método-práxis da fundamentação próprio à época pós-metafísica, gerado pela modernidade cultural europeia enquanto sociedade-cultura e consciência cognitivo-moral pós-metafísicas, isto é, pós-convencionais e descentrados: tais conceitos dão a ideia e querem exatamente significar a separação entre normatividade e base material, entre cultura e civilização material como chave-de-leitura e forma de intervenção e de enquadramento em termos de situações e sujeitos concretos, neles. Novamente, essa universalidade como condição do sentido somente é possível de ser sustentada a partir das quatro premissas e préjuízos centrais utilizados por Habermas em sua teoria filosófico-sociológica da modernidade, a saber: discurso endógeno, autorreferencial e auto-subsistente que, entretanto, ao fim e ao cabo, alcança o universalismo, o gênero humano, confundindo-se com ele e, por isso, falando em nome dele; o silenciamento sobre o e o apagamento do colonialismo como parte fundante e constitutiva do processo de modernização; a separação entre modernidade cultural, normativa, e modernização econômico-social, instrumental, purificando a primeira e condenando a segunda; e, por fim, a afirmação, dependente destas e nelas baseada, de que um método-práxis calcado na diferenciação entre normatividade e materialidade, um método-práxis sem carnalidade e politicidade (formal, imparcial, neutro e impessoal) pode - ele e somente ele - servir de chão comum para o diálogo-práxis intercultural, entre as diferenças e por elas, e não exatamente sua carnalidade, politicidade e vinculação - o que significa, evidentemente, a pressuposição, por Habermas, de que o que une o gênero humano é um princípio formal, e não uma base material em comum.

Atentemos para este ponto, que desenvolveremos mais detalhadamente agora: a racionalidade cultural-comunicativa é a estrutura formal que perpassa o gênero humano como um todo, aglutinando-o, e não algum princípio material mais específico (pense-se, por exemplo, no trabalho, de origem marxiana-marxista, que é mais particularizado, materializado, quanto, no caso de Habermas, ligado diretamente à racionalização instrumental, e não à racionalização cultural-comunicativa). Aqui, a identidade do gênero humano e o ponto comum a partir do qual o diálogo-práxis intercultural é 
possível sob a forma de procedimentalismo neutro, imparcial, formal e impessoal consistem nessa estrutura formal, e não na própria materialidade das correlações entre sociedades-culturas. Esse ponto é muito importante não apenas na definição da ética comunicativa de Habermas por meio da pragmática formal - como coroamento da correlação de modernização, racionalização, universalismo e gênero humano, da correlação de modernização e gênero humano, da correlação de universalismo e/como procedimentalismo imparcial, neutro, formal e impessoal -, mas também para entendermos, por outro lado, o porquê seja de o colonialismo não entrar na teoria da modernidade, seja, além disso, de o concretismo próprio às sociedades tradicionais, como acredita Habermas, não servir como base paradigmático-normativa comum do diálogo-práxis intercultural. A estrutura formal própria ao gênero humano, de que fala Habermas, enquanto intersecção de racionalidade cultural-comunicativa e/como procedimentalismo imparcial, neutro, formal e impessoal, é algo que somente a cultura europeia moderna teria alcançado e realizado plenamente, efetivamente, no entender do referido pensador, permitindo, por conseguinte, que o paradigma normativo da modernidade - e, em certo sentido, a própria modernização central (veja-se a noção habermasiana de segunda chance da Europa ou a sua ideia de intervenção humanitária) - seja a única base e a condição fundante, dinamizadora, orientadora e definidora da crítica, da integração, do diálogo-práxis, da emancipação. Portanto, nesse caso, a correlação de modernização como racionalização e universalismo, calcada no procedimentalismo imparcial, neutro, formal e impessoal, que parte da ideia de que existe uma estrutura formal às sociedades-culturas, ao gênero humano como um todo que permite a intermediação, ainda que mínima, leva, de um só golpe, à legitimação desse formalismo metodológico-axiológico próprio ao e representado pelo paradigma normativo da modernidade, com a consequente deslegitimação do tradicionalismo como arena, paradigma e práxis crítica, reflexiva e emancipatória. Aqui, o tradicionalismo somente consegue pensar-agir-fundamentar em termos concretistas, lançando mão de conceitos, de práticas e de valores que sempre se remetem a um objeto, a uma mágica, a uma situação e a uma autoridade materiais, concretas; em contrapartida, o sujeito epistemológico-político moderno, como filho da racionalização cultural-comunicativa e utilizando-se dela (em termos de procedimentalismo imparcial, neutro, formal e impessoal), tem condições de pensar-agir-fundamentar a partir de conceitos genéricos e formais, sem necessidade de remeter-se diretamente ao contexto e às práticas concretas e autoridades normativas de determinado contexto sociocultural ou visão de mundo 
particularista. Por isso, o tradicionalismo, incapaz de formalização porque não possuindo racionalização cultural-comunicativa madura, não serve de base e de práxis da e para a fundamentação universalista. Se ele tem algo a dizer, isso somente é possível dentro do paradigma normativo da modernidade e por meio dele, e não o contrário. Isso, inclusive, justifica, na teoria da modernidade de Habermas, a ideia de que a evolução humana é modernização, leva à modernização, enquanto superação do tradicionalismo e consolidação da sociedade-cultura e da consciência cognitivo-moral modernas, um passo, aliás, ao qual não temos mais volta, restando-nos somente, como Habermas também defende, uma radicalização da modernidade cultural (Habermas, 2002a, p. 122; Habermas, 2002b, p. 07-08).

Gostaríamos de propor, como alternativa a essa estrutura formal como base do paradigma normativo da modernidade e como forma de deslegitimação do tradicionalismo em geral enquanto paradigma normativo do diálogo-práxis, o próprio colonialismo como fundamento da teoria da modernidade - o colonialismo como teoria da modernidade - que seria, em primeira mão e fundamentalmente, uma base material que, essa sim, possibilitaria o diálogo-práxis universal, posto que torna homogêneo o processo de modernização e, principalmente, permite correlações entre as sociedadesculturas frente à modernidade, com ela. Antes disso, dois esclarecimentos. Primeiro, quando falamos em paradigma normativo da modernidade, nos referimos a alguns pressupostos teórico-políticos centrais da própria categoria de modernidade utilizada tanto na filosofia quanto na sociologia: a primeira delas e mais central, diz respeito ao fato de que se concebe a evolução humana como superação do tradicionalismo e consolidação da modernidade, o tradicionalismo como dogmatismo, a modernidade como racionalização, o tradicionalismo como contextualismo estrito, a modernidade como universalismo, o que também significa que a evolução humana é um processo cujo sentido é reto e direto, a saber, a consolidação da modernização (nesse ponto, aliás, para Habermas, as ciências sociais, a psicologia moral e até a filosofia apontam para o fato de que a modernidade é uma sociedade-cultura, uma consciência cognitivo-moral e um paradigma normativo totalmente diferentes e mais universais que $o$ tradicionalismo); a segunda delas, portanto, está na correlação de modernização, racionalização, universalismo e gênero humano, modernização e gênero humano, assim como na correlação de modernização, racionalização, crítica, reflexividade, emancipação e universalismo; a terceira delas está na ideia de que o universalismo 
epistemológico-moral próprio ao mundo pós-metafísico tem de ser exatamente o procedimentalismo imparcial, neutro, formal e impessoal relativamente aos contextos socioculturais e axiológicos particulares, fornecido pela modernidade cultural; a quarta delas consiste em que somente esse formalismo em termos de racionalização culturalcomunicativa e de procedimentalismo imparcial, neutro, formal e impessoal pode fornecer a base comum do diálogo-práxis, inclusive e porque é o núcleo ontogenético comum ao gênero humano como um todo; a quinta delas consiste no argumento de que o universalismo é a condição do particularismo, do contextualismo, e de que, por conseguinte, somente um paradigma normativo universalista pode interromper o ceticismo, o relativismo e o subjetivismo, ainda que isso, na época pós-metafísica, não signifique sua eliminação. Portanto, por paradigma normativo da modernidade estamos entendendo - e Habermas está entendendo, a filosofia e a sociologia europeias estão entendendo - exatamente o universalismo como critério do sentido, da crítica e da emancipação relativamente ao contextualismo, assim como, a partir daqui, a correlação entre modernidade, racionalização, universalismo e gênero humano, que levam à centralidade da racionalidade cultural-comunicativa e do procedimentalismo imparcial, neutro, formal e impessoal como base do diálogo-práxis intercultural, como a práxis e o paradigma por excelência de qualquer processo de justificação intersubjetivo entre a modernidade e o outro da modernidade.

Segundo, as teorias da modernidade - citamos Weber e Habermas como exemplificação, mas o mesmo vale, por exemplo, para Giddens (cf.: Giddens, 1996), em termos contemporâneos - partem da diferenciação entre modernidade europeia e todo o resto, ou sociedades desenvolvidas (primeiro mundo) e sociedades subdesenvolvidas (terceiro mundo), o que significa, na linguagem das ciências sociais europeias, o padrão evolutivo das sociedades industrializadas desenvolvidas (relativamente ao primeiro mundo, claro). De um lado, tem-se a modernidade europeia como racionalização e universalismo; de outro, tem-se o tradicionalismo em geral como dogmatismo e contextualismo; de um lado, tem-se o padrão de desenvolvimento do primeiro mundo e, de outro, tem-se o padrão subdesenvolvido do segundo, como pólos não-dependentes, separados e puros em sentido bastante estrito. Queremos chamar a atenção, aqui, para essa divisão caricata e purista entre modernidade e todo o resto como tradicionalismo (ou, depois, entre desenvolvimento e subdesenvolvimento). E queremos chamar a atenção sobre dois problemas que emergem dessa separação. O primeiro como esse 
sentido totalmente delimitado e purista, afinal $a$ modernidade não contém - a não ser com algo superado, como uma recordação apenas - o tradicionalismo e nem traços dele; o tradicionalismo, por assim dizer, não contém a modernidade - a não ser como potencialidade - e nem traços dela. Parece como se existisse uma divisão radical em termos socioculturais, civilizacionais, epistemológico-políticos, antropológicoontológicos etc. Mas essa separação e oposição puristas e diretas, como ponto de partida programático-metodológico e pré-conceito político-normativo, mostram exatamente esse abordagem bastante problemática e, diríamos nós, dificilmente sustentável da modernidade europeia por parte das teorias da modernidade, inclusive porque descamba, nas teorias da modernidade, na ideia de que o tradicionalismo não possibilita crítica, reflexividade, mobilidade e transformação sociais, emancipação e universalismo, mas a modernidade sim. No mesmo sentido, a concepção purista de modernidade cultural, sustentada a partir daqui, impede-nos de entender as patologias psicossociais como possuindo base normativa, mas apenas instrumental, lógico-técnica, o que é outro grande problema. Afinal, normatividade não gera patologias individuais e sociais? É possível negar e marginalizar alguém sem base normativa, política e moral? O segundo consiste no fato de que se fala no tradicionalismo em geral, como se todas as sociedades-culturas não-modernas tivessem uma estruturação, uma constituição e uma dinâmica evolutivas totalmente similares umas às outras. Além disso, o tradicionalismo em geral significaria que todas as sociedades-culturas não-modernas possuem o mesmo princípio integrativo, o dogmatismo calcado em fundamentações essencialistas e naturalizadas, e de que uma tal base totalmente concretista e contextual é, em sua homogeneidade, fechada, acrítica, subsumindo seus indivíduos e seus grupos nesse horizonte antropológico-ontológico totalizante e unidimensional, impedindo-lhes de agirem-pensarem-fundamentarem de modo universalista e, assim, tornando inviável o diálogo-práxis intercultural desde o, com base no próprio tradicionalismo. Mas será possível homogeneizar todas as sociedades-culturas nesse conceito de tradicionalismo em geral? Note-se que isso permite, às teorias da modernidade, recusarem que o tradicionalismo seja uma arena, uma práxis e um arcabouço axiológico que permitam seja o universalismo epistemológico-moral, seja o diálogo-práxis intercultural. Esse mesmo universalismo, entendido pelas teorias da modernidade (e por muitas filosofias políticas liberais) como procedimentalismo neutro, formal, impessoal e imparcial, seria fornecido apenas pelo paradigma normativo da modernidade, e não teria carnalidade e nem politicidade como condição do entendimento e da objetividade axiológicas, o que 
significa que o outro da modernidade, o tradicionalismo em geral, se quiser alcançar a universalidade, deve assumir as pressuposições básicas ao paradigma normativo da modernidade, acima elencadas - enquanto ele for concretista, carnal e político, enquanto ele for vinculado e dependente do contexto de emergência, não terá voz-práxis formal, imparcial, neutra e impessoal, não podendo agir-pensar-fundamentar de modo racionalizado, intersubjetivista, universalista.

Dito isso, argumentamos que é necessário aos contextos e sujeitos colonizados introduzir o colonialismo na teoria da modernidade, o colonialismo como teoria da modernidade, recusando uma de suas (das teorias da modernidade europeias) premissas centrais, a saber, a ideia de que a correlação de racionalidade cultural-comunicativa e de procedimentalismo imparcial, neutro, formal e impessoal represente a estrutura formal própria ao gênero humano como um todo e, a partir disso, que o paradigma normativo da modernidade signifique esse mesmo gênero humano, por causa exatamente dessa formalidade (em termos do procedimentalismo), podendo falar em nome dele e exigindo que qualquer discussão em nome dele e por ele seja uma discussão modernizante, desde a modernidade, por meio da modernidade. Em primeiro lugar, portanto, o colonialismo na teoria da modernidade e como teoria da modernidade satisfaz uma das exigências fundamentais do paradigma normativo da modernidade, mas rompendo com ele, a saber, a necessidade de um solo comum, de uma base comum que permita o diálogopráxis intercultural e reparatório. Como dissemos acima, sem essa base comum, em termos antropológico-ontológicos, não seria possível e nem viável a fundamentação de um paradigma normativo garantidor desse diálogo-práxis. Ora, o colonialismo possibilita essa base comum porque, em verdade, é por meio desse processo simbólicomaterial de assimilação, negação, transformação e até destruição do outro da modernidade pela modernidade que efetivamente a história da civilização ocidental tem uma de suas dinâmicas centrais, desde fins do século XV em diante. Como vimos na primeira parte, a partir de Weber e de Habermas, a definição da modernidade por si mesma constrói-se exatamente por meio de sua contraposição, oposição e superioridade em relação ao outro da modernidade, que é afastado dela, excluído dela, o que mostra que, efetivamente, não seria possível construir-se um discurso filosófico-sociológico e uma autocompreensão normativa da modernidade sobre si mesma e por si mesma (e, depois, em nome de toda a humanidade, representando-se como toda a humanidade) sem a menção, ainda que enviesada, ao outro da modernidade. O colonialismo, 
conforme o entendemos, não é uma estrutura formal, sem carnalidade e politicidade, senão que exatamente esse contexto e essa práxis simbólico-materiais que interligaram e interligam diferentes sociedades-culturas e sujeitos epistemológico-políticos a partir do paradigma da modernização então em desenvolvimento e hoje já consolidado como sistema-mundo em grande medida totalizante e unidimensional. Somente por isso se fala em civilização ocidental, em modernização ocidental e em universalismo, ou seja, somente por causa de um processo de colonização que interligou, imbricou e confrontou diferentes sociedades-culturas, diferentes sujeitos epistemológico-políticos e que, ao fim e ao cabo, acabou definindo a própria consolidação da modernidade central em sua correlação com as modernidades periféricas - pensemos, aqui, nas Américas, na África e no Oriente Médio, apenas a título de exemplo. Aliás, em relação a isso, o colonialismo na teoria da modernidade e como teoria da modernidade permite perceber-se fenômenos socioculturais e político-institucionais fundantes tanto do contexto interno à modernização central quanto dos contextos próprios à modernização periférica. Fenômenos como a escravidão, a pauperização social, a dizimação de minorias, o confronto entre as religiões institucionalizadas europeias e as visões de mundo dos povos colonizados - indígenas e negros, principalmente -, as guerras entre metrópoles por colônias e dessas metrópoles relativamente às colônias, a atual globalização econômico-cultural, o terrorismo, a imigração forçada, a xenofobia etc. são caudatários diretos do colonialismo e da correlação de modernização central e modernização periférica, guardando com eles estreita conexão. No mesmo sentido, quando olhamos para a história das ex-colônias, por exemplo o Brasil, perceberemos o quanto fenômenos próprios à colonização e detonados por ela moldaram e ainda hoje repercutem em nossa constituição sociocultural e político-institucional, como o autoritarismo político, o preconceito cultural de raça-cor, a periferização cultural-econômica, a marginalização e até a destruição das minorias, a dependência externa, a corrupção estrutural, as desigualdades socioculturais e político-normativas caudatárias da escravidão etc. $\mathrm{O}$ colonialismo na e como teoria da modernidade, por conseguinte, é chave-de-leitura e ponto de partida político-normativo que permite uma reconstrução mais sólida e mais verdadeira, mais consciente e esclarecida-esclarecedora dessa mesma teoria da modernidade.

Voltaremos sobre esse ponto - o colonialismo como princípio material, e não como estrutura formal de uma teoria da modernidade que tematiza o gênero humano - 
logo adiante. Por ora, é importante salientar-se, conforme pensamos, que o colonialismo na teoria da modernidade permite a superação disso que já chamamos de cegueira histórico-sociológica das teorias da modernidade, que leva a uma romantização e a uma superestimação acríticas e infladas do paradigma normativo da modernidade. Por cegueira histórico-sociológica entendemos aqueles três problemas fundamentais das teorias da modernidade europeias, em especial, para nosso caso aqui, da teoria da modernidade de Jürgen Habermas, a saber: (a) sua compreensão do processo de modernização europeu enquanto possuindo uma dinâmica autorreferencial, autosubsistente e endógena, um esforço de si sobre si mesma da modernidade, sem qualquer correlação seja com outras sociedades-culturas, seja com o próprio colonialismo; (b) a separação purista e o corte radical entre modernidade como racionalização e universalismo $\mathrm{e}$ todo $\mathrm{o}$ resto como tradicionalismo enquanto dogmatismo $\mathrm{e}$ contextualismo; (c) a separação mais uma vez purista entre modernidade cultural enquanto esfera puramente normativa e modernização econômico-social como esfera basicamente lógico-técnica ou instrumental, o que significa, por um lado, que a primeira é a base ontogenética da segunda e esta é a única culpada por todas as patologias psicossociais modernas; (d) por causa dessa separação entre modernidade cultural e modernização econômico-social, e apenas por causa dela, a modernidade cultural, pura e santa, é alçada ao status de puro universalismo enquanto correlação de racionalização cultural-comunicativa e procedimentalismo imparcial, neutro, formal e impessoal, de modo que, aqui, se pode correlacionar modernização, racionalização, crítica, reflexividade, emancipação e universalismo; (e) com o silenciamento sobre o e o apagamento do colonialismo da teoria da modernidade, e tendo-se por fundamento a separação entre modernidade cultural e modernização econômico-social, pode-se defender que o paradigma normativo da modernidade, baseado na modernidade cultural, é a condição fundante da crítica, da reflexividade e da emancipação, dentro e fora da modernidade, posto ser diretamente universalismo como procedimentalismo imparcial, neutro, formal e impessoal, calcado na racionalização cultural-comunicativa enquanto tendência comum ao gênero humano; (f) ainda relativamente ao silenciamento sobre e ao apagamento do colonialismo na e da teoria da modernidade, sua exclusão desta permite ao filho iluminista dessa mesma modernidade sustentar essa função salvífica e messiânica da modernidade seja sobre si mesma, seja sobre o outro da modernidade, posto ser diretamente universalista, uma sociedade-cultura e uma consciência cognitivomoral descentradas, pós-convencionais, não-egocêntricas e não-etnocêntricas; (g) em 
tudo isso, o paradigma normativo da modernidade pode, por um lado, reconstruir a gênese e o desenvolvimento da modernidade-modernização europeia como um processo endógeno, autônomo e autorreferencial da modernidade sobre si mesma, mas, ao fim e ao cabo, perceber e afirmar que esse processo representa a própria evolução do gênero humano ao longo do tempo, de modo que esse processo endógeno, interno e autosubsistente da modernidade sobre si mesma é também o processo evolutivo-constitutivo do gênero humano de um modo mais geral, o que significa que, se inicialmente o discurso filosófico-sociológico da modernidade europeia sobre si mesma buscava uma compreensão mais clara e complexa do próprio fenômeno da modernização, ao fim e ao cabo ele encontra o e se confunde com o gênero humano em um duplo sentido, a saber, permitindo afirmar-se que a evolução humana é processo evolutivo dinamizado e constituído como superação do tradicionalismo pela modernização, do dogmatismocontextualismo pela racionalização e pelo universalismo, bem como, por causa disso, de que a modernização, enquanto microcosmo desse macrocosmo mais geral que é o gênero humano, já tendo alcançado o grau efetivamente universalista, pode representar esse gênero humano como um todo (por ser o estágio final dele), pode falar em nome dele, por ele e para ele, fornecendo o paradigma normativo universalista de todos os paradigmas normativos contextualistas e particularistas.

A cegueira histórico-sociológica, portanto, possui duas características: confunde um processo civilizacional particular, no caso a Europa moderna (ou, depois, o padrão evolutivo das sociedades industrializadas desenvolvidas), com o processo ontogenético próprio ao gênero humano como um todo, de modo que a sociedade-cultura e a consciência cognitivo-moral europeias representam o apogeu evolutivo desse mesmo gênero humano e uma sociedade-cultura e uma consciência cognitivo-morais efetivamente universalistas, as primeiras a serem universalistas em termos desse mesmo gênero humano; e constrói uma caricatura da modernidade que, dependente de modo fundamental do silenciamento sobre o e do apagamento do colonialismo na e da teoria da modernidade, da separação direta entre modernidade cultural e modernização econômico-social, assim como da oposição purista entre modernidade como racionalização e universalismo versus o outro da modernidade como tradicionalismo em geral, leva à afirmação de que a modernidade europeia, em termos de sociedade-cultura e de consciência cognitivo-moral, gera o autêntico universalismo epistemológico-moral, a partir da correlação de racionalização cultural-comunicativa e de procedimentalismo 
imparcial, neutro, formal e impessoal, o que significa que ela é superior relativamente ao tradicionalismo em geral no que diz respeito à fundamentação, à construção e ao sustento de um guarda-chuva normativo de todas as diferenças, para todas elas, por todas elas, colocando-se como a única base paradigmática, política e normativa da crítica, do enquadramento e da transformação, dentro da modernidade mesma e fora dela, frente aos outros contextos. A razão de tudo isso é clara: o discurso filosóficosociológico da modernidade ligou modernização e gênero humano, modernização como gênero humano, de modo que, por outro lado, o processo do constitutivo-evolutivo do gênero humano conduz à modernização (como racionalização cultural-comunicativa e procedimentalismo imparcial, neutro, formal e impessoal), o que também significa que a modernização é o ponto de interligação entre as sociedades-culturas, exatamente por já constituir-se no processo evolutivo-constitutivo do gênero humano finalizado, consolidado, como um todo.

Ora, a cegueira histórico-sociológica das teorias da modernidade, como seu ponto de partida tanto para a reconstrução do processo de modernização europeu quanto para a fundamentação do paradigma normativo da modernidade, gera e confere uma perspectiva acrítica e totalizante a esse mesmo paradigma normativo da modernidade, a saber, (a) de que ele é a condição fundante da crítica, da reflexividade, da correção e da emancipação, (b) de que ele é autêntico universalismo, desde a correlação de racionalização cultural-comunicativa e procedimentalismo imparcial, neutro, formal e impessoal, podendo servir como guarda-chuva normativo de todas as diferenças, para todas elas e por todas elas, e (c) de que ele é o elo em termos de gênero humano, podendo constituir e orientar o diálogo-práxis intercultural. De todo modo, é claro que isso não poderia ser de outro modo, posto que se idealizou a tal modo o paradigma normativo da modernidade, fundado na e dinamizado pela modernidade cultural europeia, que não haveria outra possibilidade de universalismo que não essa: a modernidade cultural é puramente normativa, totalmente positiva, não possui mancha, pecado ou irracionalidade; ela é um esforço de si sobre si mesma, que supera o tradicionalismo via racionalização, alcançando o universalismo, isto é, uma estrutura societal-cultural e uma consciência cognitivo-moral não-egocêntricas e nãoetnocêntricas; e ela é o próprio núcleo do gênero humano em seu desenvolvimento e construção. Por outro lado, o tradicionalismo não teria condições de substituir paradigmaticamente a modernização, posto que ele não permite o universalismo, senão 
que é dogmático e preso ao e dependente do contexto, constituindo-se em uma perspectiva e em uma postura antropológicas concretistas. No mesmo diapasão, a evolução humana é superação do tradicionalismo enquanto dogmatismo e contextualismo estritos e consolidação da sociedade-cultura e da consciência cognitivomoral modernas, de modo que, aqui, a evolução humana somente pode significar e implicar em mais modernização, e não uma volta ao tradicionalismo. Por isso, a invectiva de Habermas de que é necessário radicalizar o iluminismo, isto é, a modernização, se quisermos pensar na superação das patologias que, por ironia, foram causadas pela própria modernização. De todo modo, estamos nos esquecendo de mencionar, para sermos fiéis a Habermas, de que se trata de radicalizar a modernidade cultural, posto que essas mesmas patologias causadas pela modernização são geradas pela modernização econômico-social! Ou seja, como se pode perceber aqui, o paradigma normativo da modernidade é (a) o modelo societal-cultural-paradigmático basilar, a superação do tradicionalismo e a consolidação do universalismo, de modo que qualquer análise teórico-prática o tem como padrão, meta e base analítica para avaliarse o outro da modernidade, bem como (b) ele se torna o único paradigma de si mesmo e frente ao outro da modernidade, de modo que qualquer análise e enquadramento desse outro da modernidade são feitas a partir do paradigma normativo da modernidade, por meio dele e para ele; no mesmo sentido, (c) ele se torna intocado e intocável, totalmente insubstituível, por causa da separação entre modernidade cultural e modernização econômico-social, que purifica a primeira e estigmatiza a segunda. Mas, conforme já salientamos, o ponto de partida analítico e o pré-conceito político-normativo do paradigma normativo da modernidade consistem na inferioridade do outro da modernidade frente à própria modernidade, assim como o ponto de chegada desse mesmo paradigma normativo da modernidade é a correlação intrínseca e direta entre modernização, racionalização, universalismo e gênero humano, modernização como gênero humano. Aqui, mais uma vez, a modernidade-modernização é seu único juiz, mas também é o único juiz e guia de tudo o que está fora dela, que somente pode justificar-se na medida em que assume estas pressuposições do paradigma normativo da modernidade.

É por isso que, conforme pensamos, é importante e, em verdade, fundamental que, pelo menos para nós, os filhos e filhas da modernidade periférica, os produtos enviesados - e não assumidos, negados e deslegitimados como tal - do processo de 
modernização europeu enquanto sistema-mundo-paradigma totalizante, possamos reconstruir o discurso filosófico-sociológico da modernidade, se quisermos ter voz e vez nele e a partir dele. Com efeito, conforme argumentamos ao longo do texto, as condições fundantes e definidoras do paradigma normativo da modernidade, calcadas na cegueira histórico-sociológica que esclarecemos acima, apontam para o fato de que qualquer voz-práxis, dentro e fora da modernidade, se quiser estar justificada, necessita ser testada pelo paradigma normativo da modernidade, assumindo muitas de suas pressuposições centrais, mormente a correlação de racionalização cultural-comunicativa e de procedimentalismo imparcial, neutro, formal e impessoal, e aceitando, em última instância, a própria associação, legitimadora do paradigma normativo da modernidade, entre modernização, racionalização, universalismo e gênero humano. Por outras palavras, o outro da modernidade, se quiser falar-agir universalmente - porque, como outro da modernidade, ele não fala e nem age universalmente, sua voz-práxis é sempre contextualizada, particularista e embasada no e pelo dogmatismo -, deve tornar-se moderno, deve fazê-lo por meio da assunção e da utilização do paradigma normativo da modernidade. Como dissemos, entretanto, esse paradigma normativo da modernidade é diretamente colonizador, negador, deslegitimador do outro da modernidade, não obstante o argumento habermasiano de que o paradigma normativo da modernidade é sensível às diferenças - e de que esta seria uma de suas características mais importantes, resultado direto da correlação de racionalização cultural-comunicativa e procedimentalismo imparcial, neutro, formal e impessoal (cf.: Habermas, 2012a, p. 683; Habermas, 2002b, p. 07-08). Mas a separação estrita entre modernidade e tradicionalismo em geral, com a superioridade da primeira em relação ao segundo; a separação entre modernidade cultural e modernização econômico-social, com a afirmação do caráter intocado da primeira e da (relativa) degeneração da segunda; um discurso-processo ontogenético autorreferencial, autônomo, endógeno e auto-subsistente que, ao final, descobre o próprio gênero humano, que, ao final, descobre-se como o próprio gênero humano; um discurso-processo que, por conseguinte, é a condição basilar e fundante de qualquer fala-práxis, inclusive do outro da modernidade que ele deslegitimou como fala-práxis, todas essas características e condições do paradigma normativo da modernidade, de sua auto-compreensão, levam à conclusão de que o outro da modernidade somente pode ter um lugar periférico dentro da teoria da modernidade e por ela mesma. Por isso, o paradigma normativo da modernidade deve ser reconstruído e complementado com a categoria do colonialismo enquanto o fenômeno simbólico- 
material constituinte e definidor da própria modernização, de sua própria autocompreensão, como a base material a partir da qual o diálogo-práxis da modernidade sobre si mesma, da modernidade e do outro da modernidade e, por fim, do outro da modernidade em relação à modernidade são construídos, dinamizados e realizados.

Entre outras coisas, a inserção do colonialismo na teoria da modernidade e como teoria da modernidade permitiria três pontos teórico-políticos fundamentais seja no que diz respeito à constituição e à legitimação do próprio paradigma normativo da modernidade, seja no que se refere à construção de um discurso-práxis decolonial ou anti-colonial desde as margens, desde as periferias, e por parte dos sujeitos epistemológico-políticos marginalizados, periféricos - desde o e pelo outro da modernidade. O primeiro deles é o desvelamento, a crítica e a desconstrução da cegueira histórico-sociológica assumida e utilizada pelas teorias da modernidade, por meio da ligação de e entre modernidade cultural, modernização econômico-social e colonialismo. Aqui, o colonialismo explicitaria exatamente o fundamento normativo tanto das patologias psicossociais modernas quanto, principalmente, do próprio fenômeno simbólico-material do colonialismo, de modo a negar essa associação direta de modernização, crítica, reflexividade, emancipação e universalismo, assim como a correlata imbricação de modernização, racionalização, universalismo e gênero humano, a partir da contraposição purista entre modernidade e o outro da modernidade, por meio da superioridade da primeira em relação ao segundo. O colonialismo mostraria seja a dependência da modernidade em relação ao outro da modernidade, periférico, marginalizado, excluído, mas ao mesmo tempo assimilado, seja a própria ligação entre modernidade cultural e modernização econômico-cultural enquanto momentos interdependentes de um mesmo projeto societal-cultural, antropológico-ontológico totalizante e unidimensional (na medida em que percebe o desenvolvimento humano como modernização e a si mesmo como ápice do gênero humano). Com isso, ao ligar-se modernidade cultural, modernização econômico-social e colonialismo, seria possível apontar-se para o fato de que a crítica à modernidade pode e deve desconstruir as ilusões e as caricaturas que ela fez de si mesma e para si mesma, que ela fez do outro de si mesma, como condição de sustentar-se enquanto universalidade. Ora, o colonialismo permite perceber-se a irracionalidade e a violência desse modelo de universalismo representado por um projeto societal-cultural, antropológico-ontológico e epistemológico-político que, como é o caso do paradigma normativo da modernidade, 
se auto-concebe como o próprio gênero humano, podendo falar por ele, direcioná-lo, legitimá-lo ou deslegitimá-lo.

A segunda grande contribuição teórico-política que o colonialismo pode dar à teoria da modernidade e, no caso, relativamente ao paradigma normativo da modernidade consiste em que, por meio de sua introdução naquela, a voz-práxis dos contextos socioculturais e dos sujeitos epistemológico-políticos periféricos pode construir sua própria compreensão do fenômeno da modernização de um modo geral e do paradigma normativo da modernidade em particular. Com efeito, não é uma questão ingênua, inocente e apolítica esse ponto de partida das teorias da modernidade, do paradigma normativo da modernidade, isto é, a divisão purista entre a modernidade e o outro da modernidade, com a superioridade da primeira em relação ao segundo; no mesmo sentido, não é nada ingênuo e inocente um discurso filosófico-sociológico que, se por um lado é endógeno, autorreferencial, auto-subsistente e autônomo, por outro descobre o e descobre-se como o gênero humano. Aqui, o outro da modernidade é diretamente escanteado e deslegitimado, ficando periferizado e tendo sua voz-práxis deslegitimada. Note-se, entretanto, que o outro da modernidade, na teoria da modernidade europeia, é uma construção desta, uma pressuposição do paradigma normativo da modernidade. Ele não diz sua palavra e não realiza sua práxis dentro da teoria da modernidade, senão que é engolfado, tragado, assimilado e assumido por esta, com a justificativa da correlação de modernização e gênero humano, modernização como gênero humano. A segunda grande contribuição teórico-política que a introdução do colonialismo na teoria da modernidade e como teoria da modernidade pode dar, portanto, é exatamente trazer para o centro desse mesmo discurso filosófico-sociológico da modernidade a voz-práxis das periferias e dos sujeitos epistemológico-políticos periféricos por eles mesmos, para eles mesmos, para a própria modernização. Com efeito, um dos pontos fundantes de uma posição teórico-política corretiva ao paradigma normativo da modernidade consiste exatamente na própria explicitação da fala-práxis dos excluídos por eles mesmos, do outro da modernidade por ele mesmo frente ao fenômeno simbólico-material da modernização totalizante. O colonialismo, como base e produto da modernização, leva exatamente a que o discurso filosófico-sociológico da modernidade sobre si mesma e, depois, sobre o gênero humano inevitavelmente tenha de levar em conta o outro da modernidade e, principalmente, tenha de deixar falar-agirfundamentar o outro da modernidade sobre si mesmo e por si mesmo. Doravante, o 
outro da modernidade, por meio da categoria do colonialismo, é quem construirá o discurso filosófico-sociológico da modernidade, estabelecendo suas potencialidades, mapeando suas patologias e irracionalidades e, assim, definindo o sentido paradigmático-normativo do diálogo-práxis universal, intercultural, que já não se confunde mais com modernização e com a assunção do paradigma normativo da modernidade pelo outro da modernidade, como condição da objetividade e da legitimidade de sua voz-práxis.

A terceira grande contribuição dada pela introdução do colonialismo na teoria da modernidade, pela afirmação do colonialismo como uma teoria da modernidade, por conseguinte, está na substituição do paradigma normativo da modernidade, em sua correlação de modernização, racionalização, universalismo e gênero humano, bem como em sua pressuposição da racionalização-cultural comunicativa como o núcleo comum e mediador do gênero humano (com a consequente instauração do procedimentalismo imparcial, neutro, formal e impessoal, sem carnalidade e sem politicidade, como base do diálogo-práxis intercultural), pelo próprio colonialismo como fenômeno a uma só vez simbólico e material. O colonialismo não é uma estrutura formal sem carnalidade, sem politicidade e sem vinculação; e ele não estabelece que o critério da objetividade e da justificação intersubjetivas, interculturais e universais seja a impessoalidade, a neutralidade, a imparcialidade e a formalidade, mas sim a própria vinculação dos sujeitos epistemológico-políticos e dos contextos socioculturais em sua constituição simbólico-material. Ora, o colonialismo dá essa carnalidade, politicidade, vinculação e materialidade ao diálogo-práxis interculturais, posto que aproxima e estabelece as reais ligações, em nosso caso, entre modernidade e o outro da modernidade, não como dois pólos separados, e separados de modo purista e direto e caricato, conforme estabelecido pelo paradigma normativo da modernidade, senão que como fazendo parte do mesmo processo civilizacional, antropológico-ontológico, sociocultural e epistemológicopolítico que é a modernização em sua tendência universalista, isto é, totalizante, assimilacionista e unidimensional. Com efeito, esse sentido altamente assimilacionista da modernidade pode ser percebido exatamente na sua auto-compreensão normativa que a concebe e que se concebe como gênero humano, como ápice e apogeu dele; ela também se percebe no fato de que, de acordo com o paradigma normativo da modernidade, o diálogo-práxis intercultural necessita assumir a correlação de racionalização cultural-comunicativa e de procedimentalismo imparcial, neutro, formal 
e impessoal como fundamento e dinâmica da justificação objetiva, intersubjetiva, o que significaria que o outro da modernidade teria de se tornar moderno, de assumir o paradigma normativo da modernidad para falar objetivamente, para justificar-se intersubjetivamente. Porém, quando pensamos o colonialismo como teoria da modernidade, introduzindo-o na teoria da modernidade, nós podemos, ao ligar de modo ontogenético modernidade cultural, modernização econômico-social e colonialismo, desconstruir o paradigma normativo da modernidade em sua auto-compreensão como gênero humano, como voz-práxis das minorias e dos marginalizados sem a participação delas (e com a deslegitimação delas como ponto de partida e ponto de chegada), mostrando exatamente que não existe as separações e oposições por ele assumidas (modernidade e o outro da modernidade, modernidade cultural e modernização econômico-social). Essas separações e oposições estritas e puristas são ficcionais, estilizadas, caricatas ou, por outras palavras, uma construção do paradigma normativo da modernidade por si mesmo e para si mesmo, seja para sustentar sua autocompreensão purista, casta e santa, seja, a partir daqui, para legitimar sua vocação missionária e messiânica em termos universalistas, como a consequente correlação de modernização, racionalização, universalismo e gênero humano.

Desse modo, a introdução do colonialismo na teoria da modernidade e como teoria da modernidade permite-nos, pelo menos a nós, os filhos bastardos e nãoreconhecidos de nossa matriz civilizacional, antropológico-ontológica, societal-cultural e epistemológico-política, substituirmos o paradigma normativo da modernidade, em sua correlação de racionalização cultural-comunicativa e de procedimentalismo imparcial, neutro, formal e impessoal, assim como em sua associação direta entre modernidade e gênero humano, modernidade como gênero humano, pelo conceito de reparação pelo colonialismo, em que a base de intersecção entre as sociedades-culturas e as reivindicações político-normativas reparatórias são dadas pelo próprio fenômeno normativo-material do colonialismo. Nesse caso, de guia e voz-práxis universais, a modernidade-modernização ocidental passa a ser ré no tribunal das sociedades-culturas e por meio dos sujeitos epistemológico-políticos subalternos, periferizados, que podem exigir seja uma reconstrução epistêmica mais justa, fiel e crítica do processo de modernização ocidental, seja certos direitos político-normativos reparatórios pelo colonialismo simbólico-material, pela negação normativa e pela destruição material das sociedades-culturas e das vidas humanas dizimadas pelo rolo compressor da 
modernização totalizante. Note-se que os dois pontos são fundamentais. Primeiro, a reconstrução do processo evolutivo da modernização social como um todo, naquele tripé de modernidade cultural, modernização econômico-social e colonialismo, a partir do reconhecimento de que o outro da modernidade, periférico, marginalizado, negado e, de modo mais dramático, totalmente caricaturizado, é uma construção da própria modernidade, sem que ele exprimisse sua voz-práxis e sem que ele participasse nesse processo construtivo - aliás, ele é sempre visto de fora, a partir da análise objetiva, imparcial, neutra e impessoal do antropólogo exótico, do cientista social asséptico, do filósofo messiânico e, por fim, da intervenção política salvífica em nome dos direitos humanos, da democracia e do desenvolvimento. Segundo, a práxis político-institucional reparatória em relação às chagas do colonialismo, que poderia ser assumida de vários modos: renda básica de cidadania universal, controle da globalização econômicocultural calcada tanto no paradigma normativo da modernidade (e sua caricatura do tradicionalismo em geral, do outro da modernidade) quanto na dominação geopolítica e geoeconômica estratégicas, fim das guerras colonialistas e imperialistas, política de direitos humanos, reformulação do desenvolvimento socioeconômico global, controle do capital financeiro, combate ao desemprego e subemprego e à exploração do trabalho, acolhimento dos refugiados etc.

Sobretudo, pelo menos para nós, os filhos e filhas bastardos e não-reconhecidos do paradigma normativo da modernidade e por ele (como construção dele, em verdade), precisamos reconstruir o discurso filosófico-sociológico da modernidade por nós mesmos, de modo a que nossa voz-práxis, a voz-práxis dos sujeitos epistemológicopolíticos marginalizados e dos contextos socioculturais periferizados possam dizer como veem, o que pensam e como querem reformular o processo de modernização, tanto em termos normativos quanto em termos materiais. Com efeito, aqui está o desafio mais agudo, pungente e emancipatório para as periferias político-epistêmicas, socioculturais e econômicas, a saber, dar centralidade à voz-práxis dos próprios marginalizados por eles mesmos e, com eles e por eles, buscar alternativas de integração, desenvolvimento e auto-compreensão, uma tarefa que não pode ser definida de fora no duplo sentido do termo: pelo uso de paradigmas estranhos, alienígenas e até negadores desses sujeitos epistemológico-políticos marginalizados; ou mesmo pela intervenção de sujeitos epistemológico-políticos extemporâneos ao próprio contexto, sem nenhuma vinculação com ele que não o seu ideal messiânico e salvífico alienígena 
e pretensioso. Para as academias das periferias e elas mesmas periféricas, que vivem das migalhas e das dinâmicas construídas nos e pelos centros epistêmico-políticos, a tarefa da descolonização do pensamento-práxis é dupla: primeiro, reconfigurarem seus paradigmas e proposições político-normativos, levando a sério o fato do colonialismo como teoria da modernidade e, com isso, estabelecendo a reparação pelo colonialismo como práxis crítico-corretiva sobre a modernidade - aliás, em relação a isso, há desenvolvimentos teórico-políticos muito consistentes e provocativos em nossas periferias e desde elas (cf.: Fanon, 1968; Dussel, 1993; Freire, 1987; Mignolo, 2003, 2007; Spivak, 2010; Bhabha, 1998; Mbembe, 2014, 2001; Quijano, 1992); segundo, e talvez mais revolucionário, transformar a academia exatamente na voz-práxis das vítimas, dos marginalizados, dos sujeitos epistemológico-políticos e dos contextos socioculturais periferizados, por eles mesmo e para eles mesmos. Esse passo é o mais difícil e o mais revolucionário, porque significa romper com a tendência, própria ao paradigma normativo da modernidade, de falar pelos marginalizados, pelas vítimas, em nome delas, como se o teórico social pudesse assumir por si e para si, desde seu paradigma descolado da práxis político-normativa, o sentido, os problemas, as dores e as potencialidades das vítimas, sem a voz-práxis dessas mesmas vítimas, desses mesmos sujeitos epistemológico-políticos marginalizados. Nesse sentido, ainda está por nascer e se consolidar o passo verdadeiramente revolucionário dos sujeitos epistemológico-políticos marginalizados e colonizados, a saber, uma academia como voz-práxis das vítimas por elas mesmas, que poderiam substituir ou pelo menos mediar os saberes e as práticas racionais-científicos gerados e legitimados pelo paradigma normativo da modernidade por uma retomada dos valores, das práticas e dos símbolos dos grupos marginalizados por eles mesmos. Porque, em última instância, o paradigma normativo da modernidade somente será implodido em sua correlação de modernidade e gênero humano, quando a construção do saber e a formulação de proposições políticonormativas forem feitas pelos próprios marginalizados em sua voz-práxis e desde ela, mas de modo tal a pôr em xeque toda a estrutura epistêmico-política racional própria de nossas instituições políticas, culturais e científicas pela afirmação da centralidade dos sujeitos epistemológico-políticos outros que a modernidade, pela sua participação insubstituível e irrepresentável, para além e negadora do cientificismo, isto é, da tendência de o teórico substituir os sujeitos marginalizados, periféricos e excluídos, falando por eles e em nome deles desde seu paradigma cientificista fortemente institucionalizado, neutro, imparcial, impessoal e formal. 
Nesse caso, mas somente nesse caso, a título de conclusão, seria verdadeiro e efetivo o dito de Wittgenstein no Tratado lógico-filosófico, isto é, de que a academia percebeu-se incapaz de dizer-representar o oprimido e de falar-agir-fundamentar em nome dele (exigindo dele, inclusive, que sua voz-práxis torne-se científica, acadêmica, institucionalizada), o que significa que ela serrou de uma vez por todas a própria base em que se sustentava sua ilusão (o cientificismo do paradigma normativo da modernidade), percebendo, em grande medida, sua impotência teórica, política e normativa sem a própria voz-práxis do oprimido, do marginalizado e do excluído por ele mesmo, para ele mesmo, dirigida também à própria modernidade. Nesse caso, portanto, o dito de Wittgenstein seria verdadeiro e efetivo porque não seria apenas um gesto estético, apolítico e fatalista do sujeito moderno desiludido com a modernidade relativamente à impossibilidade da verdade, da justificação objetiva (pelo menos em termos de ciências humanas e sociais, porque lhe permanece certo ranço e certo resquício cientificistas), sujeito esse que, uma vez desiludido, entrega-se ao desânimo e ao ostracismo apolíticos, mas sim porque ele religa a verdade, a justificação e a política à voz-práxis dos oprimidos, dos marginalizados e dos excluídos como a fonte, a base e os sujeitos da esperança, da crítica, da reflexividade e da emancipação, irrepresentáveis e insubstituíveis pelo acadêmico objetivo, pelo paradigma universal assimilacionista e pelo político institucionalista.

\section{Referências bibliográficas}

BHABHA, Homi K. O Local da Cultura. Belo Horizonte: Editora da UFMG, 1998.

DUSSEL, Enrique. 1492, o encobrimento do outro: a origem do mito da modernidade. Petrópolis: Vozes, 1993.

FANON, Franz. Os condenados da terra. Rio de Janeiro: Civilização Brasileira, 1968.

FORST, Rainer. Contextos da justiça: filosofia política para além de liberalismo e comunitarismo. São Paulo: Boitempo, 2010.

FREIRE, Paulo. Pedagogia do oprimido. Rio de Janeiro: Paz e Terra, 1987.

GIDDENS, Anthony. Para além da direita e da esquerda: o futuro da política radical. São Paulo: Editora da UNESP, 1996.

HABERMAS, Jürgen. Teoria do agir comunicativo (vol. I): racionalidade da ação e racionalização social. São Paulo: Martins Fontes, 2012a. 
HABERMAS, Jürgen. Teoria do agir comunicativo (vol. II): sobre a crítica da razão funcionalista. São Paulo: Martins Fontes, 2012b.

HABERMAS, Jürgen. Diagnósticos do tempo: seis ensaios. Rio de Janeiro: Tempo Brasileiro, 2005.

HABERMAS, Jürgen. Direito e democracia: entre facticidade e validade (Vol. I). Rio de Janeiro: Tempo Brasileiro, 2003a.

HABERMAS, Jürgen. Direito e democracia: entre facticidade e validade (Vol. II). Rio de Janeiro: Tempo Brasileiro, 2003b.

HABERMAS, Jürgen. $O$ discurso filosófico da modernidade: doze lições. São Paulo: Martins Fontes, 2002a.

HABERMAS, Jürgen. A inclusão do outro: estudos de teoria política. São Paulo: Loyola, $2002 b$.

HABERMAS, Jürgen. Problemas de legitimación en el capitalismo tardio. Madrid: Editorial Cátedra, 1999.

HABERMAS, Jürgen. Ensayos políticos. Barcelona: Ediciones Península, 1997.

HABERMAS, Jürgen. La necesidad de revisión de la izquierda. Madrid: Editorial Tecnos, 1991.

HABERMAS, Jürgen. Para a reconstrução do materialismo histórico. São Paulo: Brasiliense, 1990a.

HABERMAS, Jürgen. Pensamento pós-metafísico: ensaios filosóficos. Rio de Janeiro: Tempo Brasileiro, 1990b.

HABERMAS, Jürgen. Consciência moral e agir comunicativo. Rio de Janeiro: Tempo Brasileiro, 1999.

HONNETH, Axel. Luta por reconhecimento: a gramática moral dos conflitos sociais. São Paulo: Editora 34, 2003.

HONNETH, Axel. Reificación: un estúdio en la teoría del reconocimiento. Buenos Aires: Katz, 2007.

MBEMBE, Achille. Crítica da razão negra. Lisboa: Antígona, 2014.

MBEMBE, Achille. On postcolony. California: University of California Press, 2001.

MIGNOLO, Walter. La idea de América Latina: la herida colonial y la opción decolonial. Barcelona: Editorial Gedisa, 2007.

MIGNOLO, Valter. Histórias locais/projetos globais: colonialidade, saberes subalternos e pensamento liminar. Belo Horizonte: Editora UFMG, 2003.

QUIJANO, Aníbal. "Colonialidad y modernidad/racionalidad”, Perú Indig., vol. 13, nº 29, p. 11-20, 1992.

PIVAK, Gayatri C. Pode o Subalterno Falar? Belo Horizonte: Editora da UFMG, 2010. 
WEBER, Max. Ensayos sobre sociología de la religión (T. I). Madrid: Taurus, 1984.

Submetido em maio de 2017

Aceito em Junho de 2017. 